Louisiana State University

LSU Digital Commons

Faculty Publications

Department of Oceanography \& Coastal

Sciences

$10-2007$

\title{
Hypoxia in the northern Gulf of Mexico: Does the science support the Plan to Reduce, Mitigate, and Control Hypoxia?
}

Nancy N. Rabalais

R. Eugene Turner

B.K. Sen Gupta

D. F. Boesch

P. Chapman

See next page for additional authors

Follow this and additional works at: https://digitalcommons.Isu.edu/oceanography_coastal_pubs

Digitart of the Oceanography Commons

Commons

Network

Logo 
Authors

Nancy N. Rabalais, R. Eugene Turner, B.K. Sen Gupta, D. F. Boesch, P. Chapman, and M. C. Murrell 


\title{
Hypoxia in the Northern Gulf of Mexico: Does the Science Support the Plan to Reduce, Mitigate, and Control Hypoxia?
}

\author{
N. N. Rabalais ${ }^{1, *}$, R. E. Turner ${ }^{2}$, B. K. Sen Gupta ${ }^{2}$, D. F. Boesch ${ }^{3}$, P. Chapman ${ }^{4}$, and \\ M. C. MurRELL ${ }^{5}$ \\ ${ }^{1}$ Louisiana Universities Marine Consortium, Chauvin, Louisiana 70344 \\ ${ }^{2}$ Louisiana State University, Baton Rouge, Louisiana 70803 \\ ${ }^{3}$ University of Maryland Center for Environmental Science, Cambridge, Maryland 71613 \\ ${ }^{4}$ Texas A $\mathcal{E}^{2} M$ University, College Station, Texas 77843 \\ ${ }^{5}$ U.S. Environmental Protection Agency, Gulf Ecology Division, Gulf Breeze, Florida 32561
}

\begin{abstract}
We update and reevaluate the scientific information on the distribution, history, and causes of continental shelf hypoxia that supports the 2001 Action Plan for Reducing, Mitigating, and Controlling Hypoxia in the Northern Gulf of Mexico (Mississippi River/Gulf of Mexico Watershed Nutrient Task Force 2001), incorporating data, publications, and research results produced since the 1999 integrated assessment. The metric of mid-summer hypoxic area on the LouisianaTexas shelf is an adequate and suitable measure for continued efforts to reduce nutrients loads from the Mississippi River and hypoxia in the northern Gulf of Mexico as outlined in the Action Plan. More frequent measurements of simple metrics (e.g., area and volume) from late spring through late summer would ensure that the metric is representative of the system in any given year and useful in a public discourse of conditions and causes. The long-term data on hypoxia, sources of nutrients, associated biological parameters, and paleoindicators continue to verify and strengthen the relationship between the nitratenitrogen load of the Mississippi River, the extent of hypoxia, and changes in the coastal ecosystem (eutrophication and worsening hypoxia). Multiple lines of evidence, some of them representing independent data sources, are consistent with the big picture pattern of increased eutrophication as a result of long-term nutrient increases that result in excess carbon production and accumulation and, ultimately, bottom water hypoxia. The additional findings arising since 1999 strengthen the science supporting the Action Plan that focuses on reducing nutrient loads, primarily nitrogen, through multiple actions to reduce the size of the hypoxic zone in the northern Gulf of Mexico.
\end{abstract}

\section{Introduction}

The development, extent, and persistence of low oxygen concentrations in bottom waters of the continental shelf of the northern Gulf of Mexico were unknown until the first systematic mapping and monitoring of oxygen began in 1985 (Rabalais et al. 1991). At that time, shelf hypoxia (defined here as dissolved oxygen levels at or below $\left.2 \mathrm{mg} \mathrm{l}^{-1}\right)$ was recorded as localized and ephemeral (Turner and Allen 1982). Since then, a large volume of data has been collected and numerous papers and reports have been published that increased our understanding of the seasonal and interannual distribution of hypoxia and its variability, history, and dynamical causes.

An Integrated Assessment (CENR 2000) of the causes, consequences, and actions needed to reduce hypoxia was completed and an Action Plan for Reducing, Mitigating, and Controlling Hypoxia in the Northern Gulf of Mexico (Mississippi River/ Gulf of Mexico Watershed Nutrient Task Force 2001) was endorsed by federal agencies, states, and

\footnotetext{
* Corresponding author; tele: 985/851-2801; fax: 985/8512874; e-mail: nrabalais@lumcon.edu
}

tribal governments. The Action Plan calls for a longterm adaptive management strategy coupling management actions with enhanced monitoring, modeling and research, and reassessment of accomplishments and environmental indicators at five-year intervals.

This paper is a component of the first reassessment, updating the earlier reports (Rabalais et al. 1999, 2002a,b) that considered publications and observations made through 1998. We review herein new information on the spatial and temporal (seasonal, annual, and long term) characteristics of hypoxia on the northern Gulf of Mexico shelf developed since the Integrated Assessment and summarize the current understanding of the onset, extent, and duration of the hypoxic zone. We also address the relationships between long-term trends in the extent, duration, and severity of hypoxia and both increased nutrient loading and other environmental factors that may influence hypoxia, evaluating the degree to which these relationships are understood and quantified. We then answer two questions: Do new research contributions and understanding of the science supporting the Action Plan justify the prior conclusions of the Integrated 
Assessment concerning increased nitrogen loads, eutrophication, and worsening hypoxia and management scenarios to reduce nitrogen loads to the northern Gulf of Mexico? and Do new research findings give us cause to alter the concepts that support management goals intended to reduce nitrogen loading from the Mississippi River?

\section{Background}

The Mississippi River forms the largest watershed on the North American continent with an annual average discharge of $580 \mathrm{~km}^{3}$ into the northern Gulf of Mexico through two main distributaries: the birdfoot delta southeast of the city of New Orleans, Louisiana, and the Atchafalaya River delta $200 \mathrm{~km}$ to the west (Meade 1995). The Mississippi and Atchafalaya rivers are the primary sources of fresh water, nitrogen, and phosphorus to the northern Gulf of Mexico, delivering $80 \%$ of the freshwater inflow, $91 \%$ of the estimated annual nitrogen load, and $88 \%$ of the phosphorus load (Dunn 1996). If only streams between and inclusive of the Trinity River (Galveston, Texas) and the Mississippi River delta are considered-those most likely to influence the zone of hypoxia-the Mississippi and Atchafalaya rivers account for $96 \%$ of the annual freshwater discharge, $98.5 \%$ of the annual nitrogen load, and $98 \%$ of the total annual phosphorus load.

The fresh water, sediments, and dissolved and particulate materials are carried predominantly westward along the Louisiana-Texas inner to mid continental shelf, especially during peak spring discharge (Rabalais et al. 1996; Smith and Jacobs 2005). Although the area of the discharge's influence is an open continental shelf, the magnitude of flow, annual current regime, and average 75$d$ residence time for fresh water all suggest that the shelf receiving the fresh water behaves as an unbounded estuary stratified for much of the year (Dinnel and Wiseman 1986). The stratification is due primarily to salinity differences, and the stratification intensifies in summer with thermal warming of surface waters (Wiseman et al. 1997). The primary pycnocline depth varies seasonally with discharge and physical mixing from $3-5 \mathrm{~m}$ to 10 $15 \mathrm{~m}$ in a $20-\mathrm{m}$ water column (Rabalais and Turner 2001; Rabalais et al. 2002c). A secondary temperature-controlled pycnocline at 10 to $15 \mathrm{~m}$ depth in a 20-m water column often caps the hypoxic water mass (Wiseman et al. 1997).

Seasonal hypoxia of bottom waters in this region is the result of the strong and persistent stratification coupled with the high organic production in overlying surface waters that is fueled by riverderived nutrients (CENR 2000). The nutrients delivered from the Mississippi River Basin support the primary productivity within the immediate vicinity of the river discharges as well as across the broader Louisiana and upper Texas continental shelf. The flux of fixed carbon in the form of senescent phytoplankton, zooplankton fecal pellets, or aggregates to the lower water column and seabed provides a large carbon source for decomposition by aerobic bacteria. Its decomposition consumes dissolved oxygen in the water column at a higher rate than resupply from the upper water column in a stratified water column, leading to hypoxia in large portions of the water column for months at a time from the spring to the fall (Rabalais and Turner 2001; Rabalais et al. 2002a,b).

Demersal fishes, crabs, and shrimp will attempt to move away from oxygen concentrations less than $2 \mathrm{mg} \mathrm{l}^{-1}$, and few marine animals survive in prolonged exposure to oxygen concentrations below that level. The hypoxic area is popularly known as the Dead Zone. The oxygen deficient waters are not just confined to a bottom layer, but may extend well up into the water column; e.g., the hypoxic water mass may occupy half of the lower water column (Rabalais and Turner 2001). Hypoxia, as a symptom of eutrophication due to nutrient enrichment, is a growing problem around the world (Diaz and Rosenberg 1995; Boesch 2002; Diaz et al. 2004). The extent and persistence of hypoxia on the LouisianaTexas shelf makes the Gulf of Mexico Dead Zone one of the most extensive manifestations of coastal eutrophication.

\section{Dimensions AND VARIABILITY OF HyPOXIA}

\section{0-km Scale}

The extent of hypoxia primarily in July averaged $13,500 \mathrm{~km}^{2}$ from 1985 to 2007 , with a range from negligible in 1988 (a summer drought year for the Mississippi River basin) to 22,000 $\mathrm{km}^{2}$ in 2002. An average of $8,200 \mathrm{~km}^{2}$ from 1985 to 1992 increased to an average of $15,900 \mathrm{~km}^{2}$ over the next $15 \mathrm{yr}$ (Rabalais et al. unpublished data). The maximal extent of bottom-water hypoxia measured was 22,000 km² in 2002 (Rabalais and Turner 2006). The five-year average size of bottom-water hypoxia in the Gulf of Mexico for 2003-2007 was $10,500 \mathrm{~km}^{2}$ (Fig. 1; Rabalais et al. unpublished data), which is well above the Action Plan goal of $5,000 \mathrm{~km}^{2}$.

The mid-summer hypoxic water mass is distributed across the Louisiana shelf west of the Mississippi River and onto the upper Texas coast (examples in Fig. 2; Rabalais and Turner 2001; Rabalais et al. 2002a). Hypoxia extends from nearshore to as much as $125 \mathrm{~km}$ offshore and in water depths extending from the shore in $4-5 \mathrm{~m}$ up to $60 \mathrm{~m}$ deep. Mid-summer hypoxia usually extends along a single continuous zone, but may occur in distinct areas west of the Mississippi and Atchafalaya River 


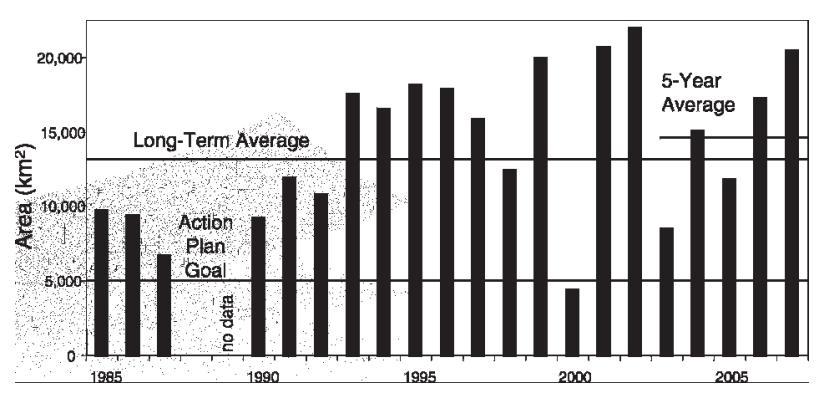

Fig. 1. Estimated bottom water extent of hypoxia (dissolved oxygen $<2 \mathrm{mg} \mathrm{l}^{-1}$ ) for mid-summer cruises, superimposed with a long-term average, a five-year average for 2002-2007 and the 2015 goal of $5,000 \mathrm{~km}^{2}$ (Rabalais unpublished data).

deltas. The bottom water between these two areas is typically depleted in oxygen (less than $3 \mathrm{mg} \mathrm{l}^{-1}$; Fig. 2, 1986 data). Variations in the distribution are also caused by the prevailing oceanographic conditions (e.g., 1998 when persistent currents from the west constrained the hypoxic region to a more easterly location, see Fig. 2) or disruption of stratification by tropical storms and hurricanes (e.g., 2003, 2005 in Fig. 1) within two weeks prior to the mapping. Hypoxia may extend onto the upper Texas coast as far as Freeport, Texas $\left(95^{\circ} 20^{\prime} \mathrm{W}, 10-20 \mathrm{~m}\right.$ water depth), during periods of high discharge and delayed return of currents from the west (Pokryfki and Randall 1987; Harper et al. 1981, 1991; Rabalais et al. 1999, unpublished data).

There are only a few sequential summer surveys that document the size of hypoxia (Rabalais et al. 1999), and the spatial extent over which the hypoxic area persists is unknown. Additional data during summer have been acquired from studies conducted in support of modeling, benthic and pelagic biological processes, distribution of demersal organisms, and finer-scale resolution of physical structure and biological communities. These data (Rabalais et al. 1999, unpublished data; DiMarco et al. unpublished data; Murrell et al. unpublished data) demonstrate the persistence of hypoxia over large areas $\left(>10,000 \mathrm{~km}^{2}\right)$ from two to three weeks up to one and a half months. The persistence of hypoxia for periods of several months is seen in data acquired from moored instrument arrays (see below).

Data from 2005 represent the best temporal coverage over larger areas, albeit not equivalent sampling areas (DiMarco et al. unpublished data; Murrell et al. unpublished data; Rabalais et al. unpublished data), when hypoxia is likely to be developing or dissipating (Fig. 3). A combination of March, April, May, and September cruise data indicate either a narrow band of hypoxia nearshore or the occurrence of hypoxia at shallow stations in

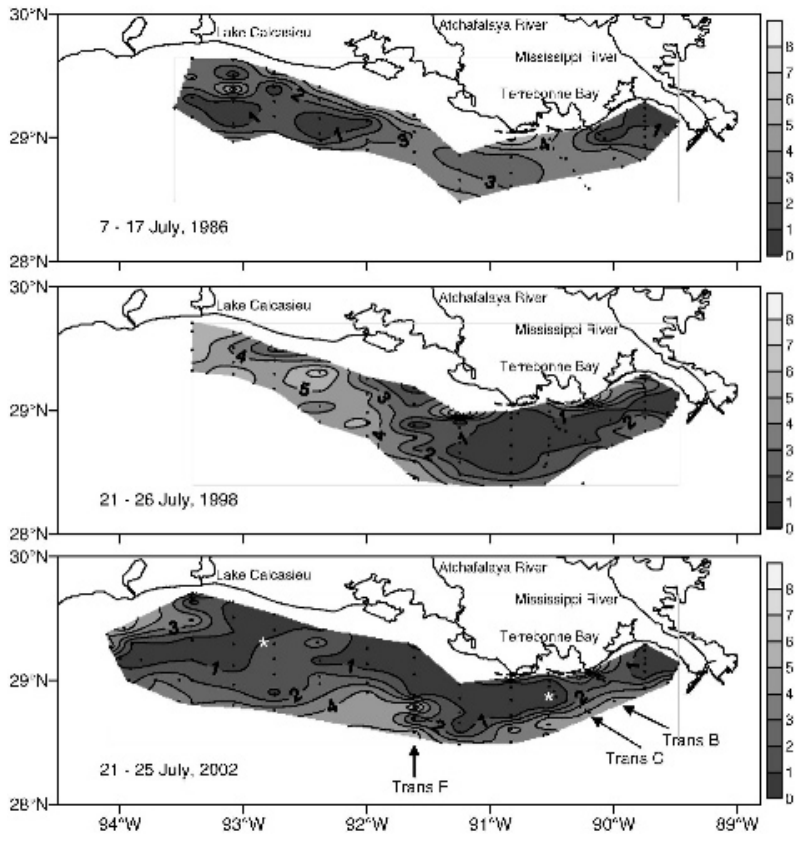

Fig. 2. Bottom water oxygen distributions for summer cruises in 1986, 1998, and 2002 (modified from Rabalais et al. 2002c). Isopleths were contoured in Surfer 8 using ordinary point Kriging. An anisotropy ratio of 2 was applied to account for the general east-west direction of the bathymetric contours. Transects B, C, and F identified on the 2002 panel; asterisk on transect C indicates location of observing system station; asterisk for station I3 indicates location of station for paleoindicators from the western Louisiana shelf.

the Louisiana Bight and off Atchafalaya Bay in those months. Other shelfwide cruises in October, November, and December indicate no hypoxia.

The 2005 summer distribution of hypoxia (Fig. 3) was affected by a series of storms. In early July 2005 there was a large area of hypoxia off the southwestern Louisiana coast. Before the late July mapping of hypoxia, Hurricanes Cindy and Dennis affected the Louisiana shelf. The late July distribution was less than predicted (Turner et al. 2005, 2006), but the hypoxia was still fairly well formed on the southwestern shelf. Mid-August 2005 hypoxia was patchier than the July distribution. Hurricane Katrina made landfall at the end of August and disrupted hypoxia in depths less than $25 \mathrm{~m}$ on transect $\mathrm{C}$, but it reformed in the shallow waters of the Louisiana Bight a few weeks later. A series of frontal passages and Hurricane Rita in September dissipated the hypoxia for the remainder of the year.

The incidents of hypoxia east of the Mississippi River delta are infrequent, short-lived, and limited in extent (summarized in Rabalais et al. 2002a). Hypoxia east of the Mississippi River occurs more frequently during flood stages of the Mississippi River when summer currents move the river plume 

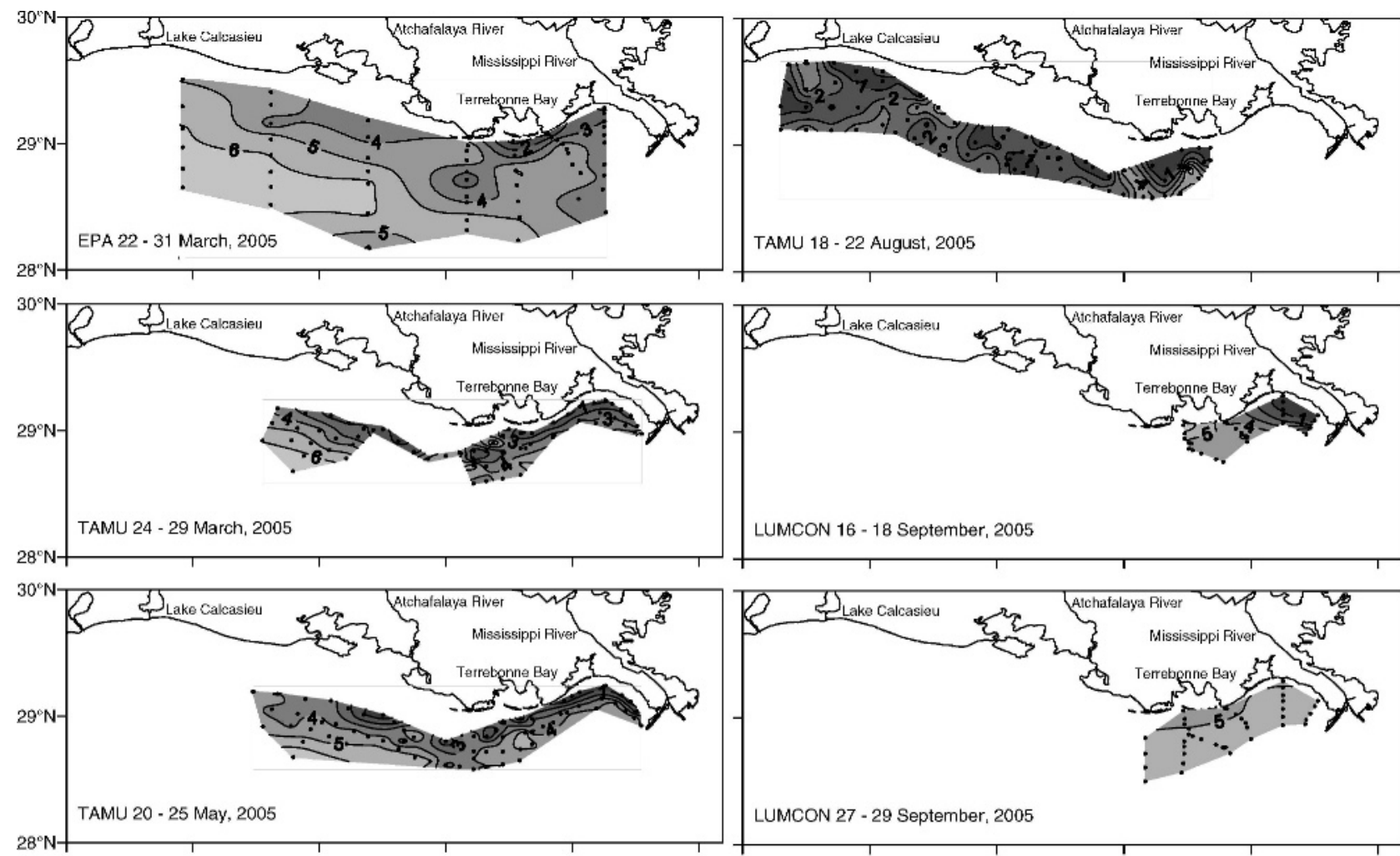

LUMCON 16 - 18 September, 2005
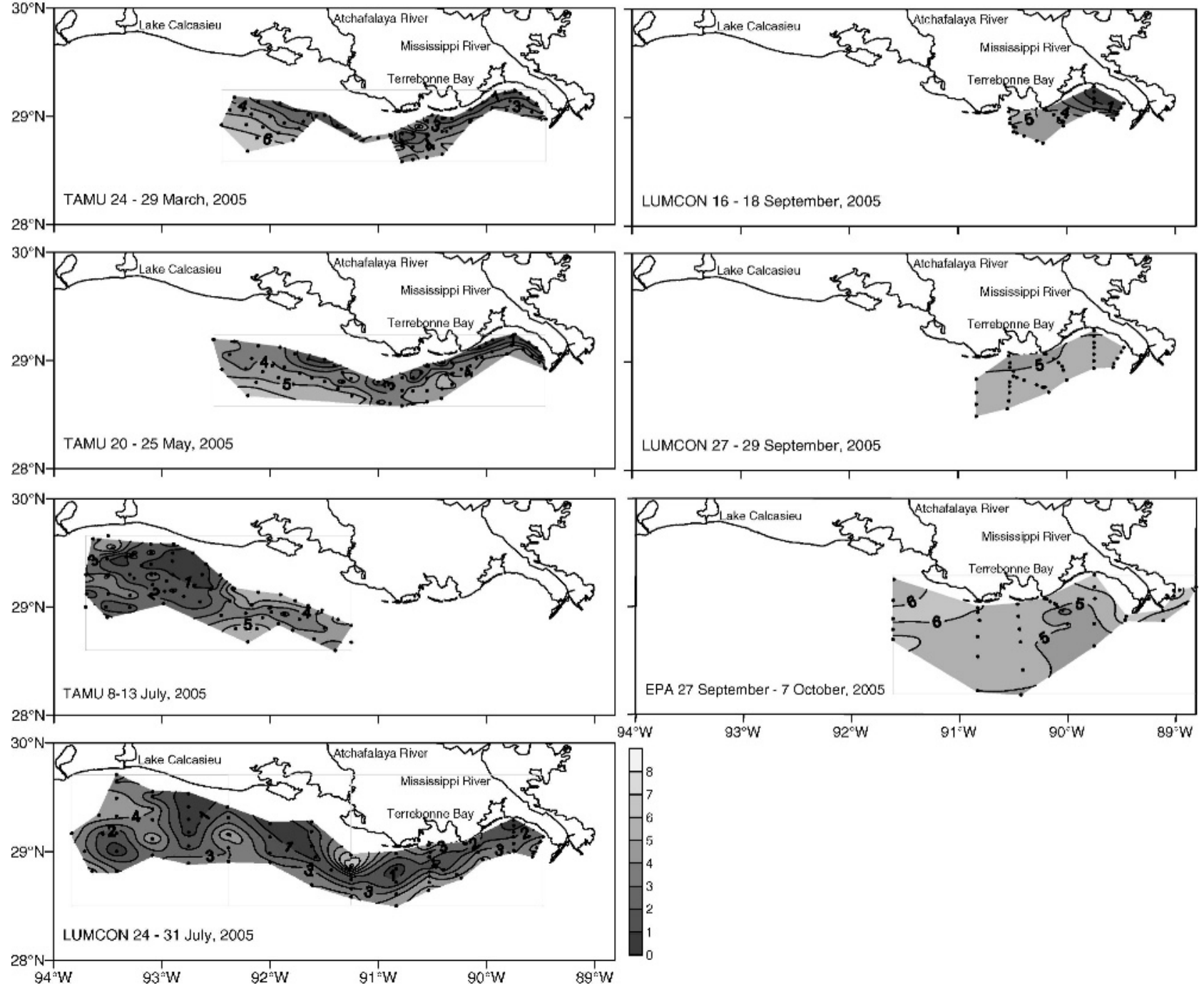

Fig. 3. Dissolved oxygen contours $\left(\mathrm{mg} \mathrm{l}^{-1}\right)$ for cruises in 2005. Isopleths were contoured in Surfer 8 using ordinary point Kriging. An anisotropy ratio of 2 was applied to account for the general east-west direction of the bathymetric contours. Unpublished data of N. N. Rabalais, Louisiana Universities Marine Consortium (LUMCON), M. C. Murrell, U. S. Environmental Protection Agency, Gulf Breeze, Florida (EPA), and S. DiMarco (TAMU) and their colleagues in hypoxia research. Data source and periods are identified in each panel.

to the east of the birdfoot delta (Rabalais 1992). A more recent and systematic study of hypoxia east of the Mississippi River (Brunner unpublished data) indicated a shallow lens of hypoxic water $(0.5-1.5 \mathrm{~m}$ thick) over an area of $200 \mathrm{~km}^{2}$ on August 23-24,
2006. There is no evidence that the area of low oxygen forms a continuous band around the delta based on limited data where both sides of the delta were surveyed (Turner and Allen 1982; National Marine Fisheries Service SEAMAP unpublished data). 


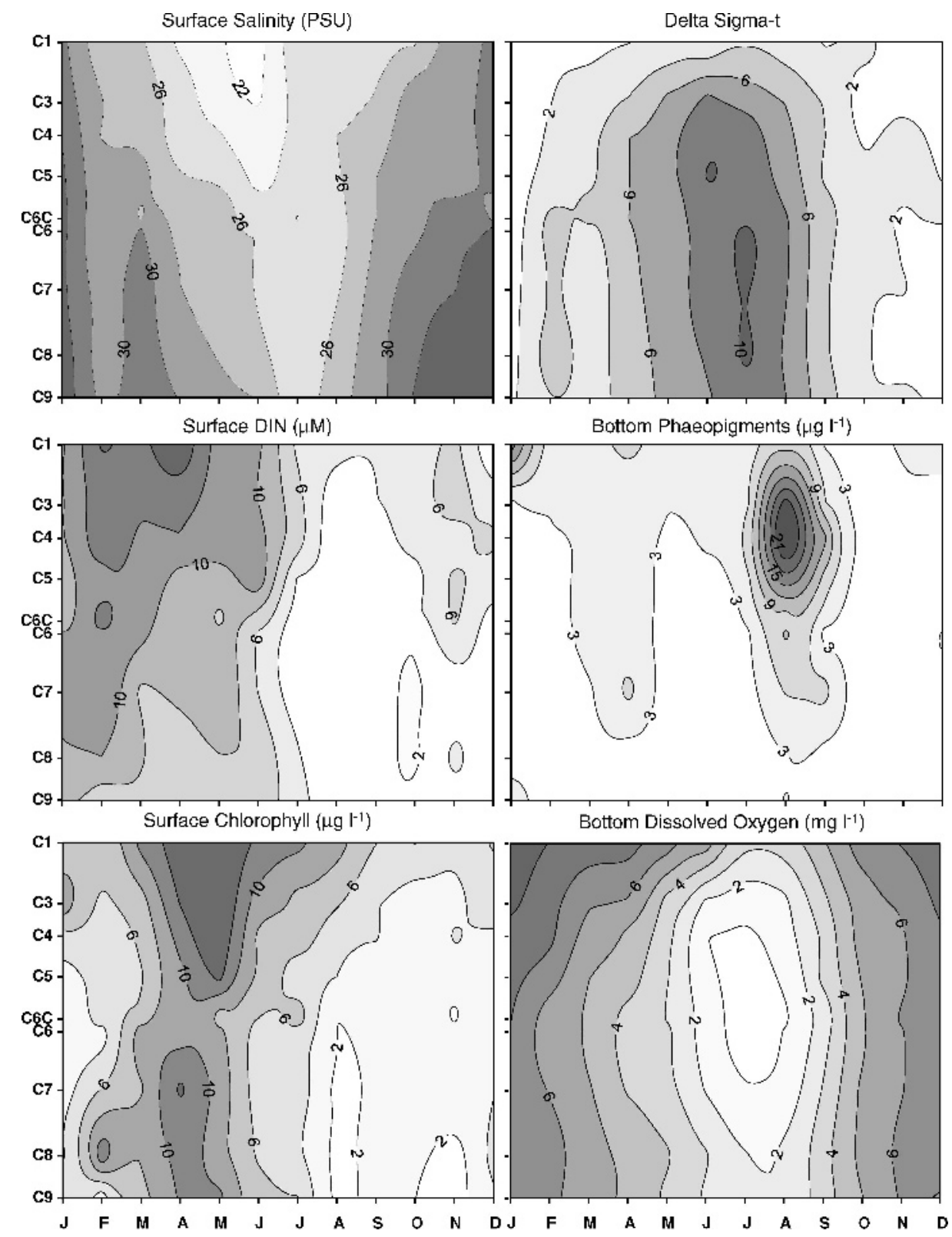

Fig. 4. Water column parameters along transect C (location in Fig. 2) from station C1 inshore at $5 \mathrm{~m}$ to C9 offshore at $30 \mathrm{~m}$, JanuaryDecember 1985-2001. Modified from Rabalais et al. (2002c).

\section{0-km Scale}

Frequent sampling on transect C (Fig. 4) on the southeastern Louisiana coast off Terrebonne Bay indicates that hypoxia occurs from as early as late February through early October and nearly continuously from mid May through mid September (Rabalais et al. 1999, 2002a). Hypoxia there is rare in late fall and winter.

Data from transects C and F off Atchafalaya Bay (Fig. 2) allow for the generation of monthly averaged conditions that depict long-term conditions in the two areas (Figs. 4 and 5). The data span 20 yr for transect C (Rabalais et al. 2002c), but there are fewer data for transect $\mathrm{F}$, for which bimonthly hypoxia and related parameter surveys began in 2001 ( $\mathrm{n}=3$ or 4 data points per station month versus $\mathrm{n} \approx 150$ for transect $\mathrm{C}$ ). The limited data for transect $\mathrm{F}$ may create spurious plots in response to annual variation, but the data presented in Fig. 5 are the best available temporal series for that portion of the shelf, provide newly synthesized 

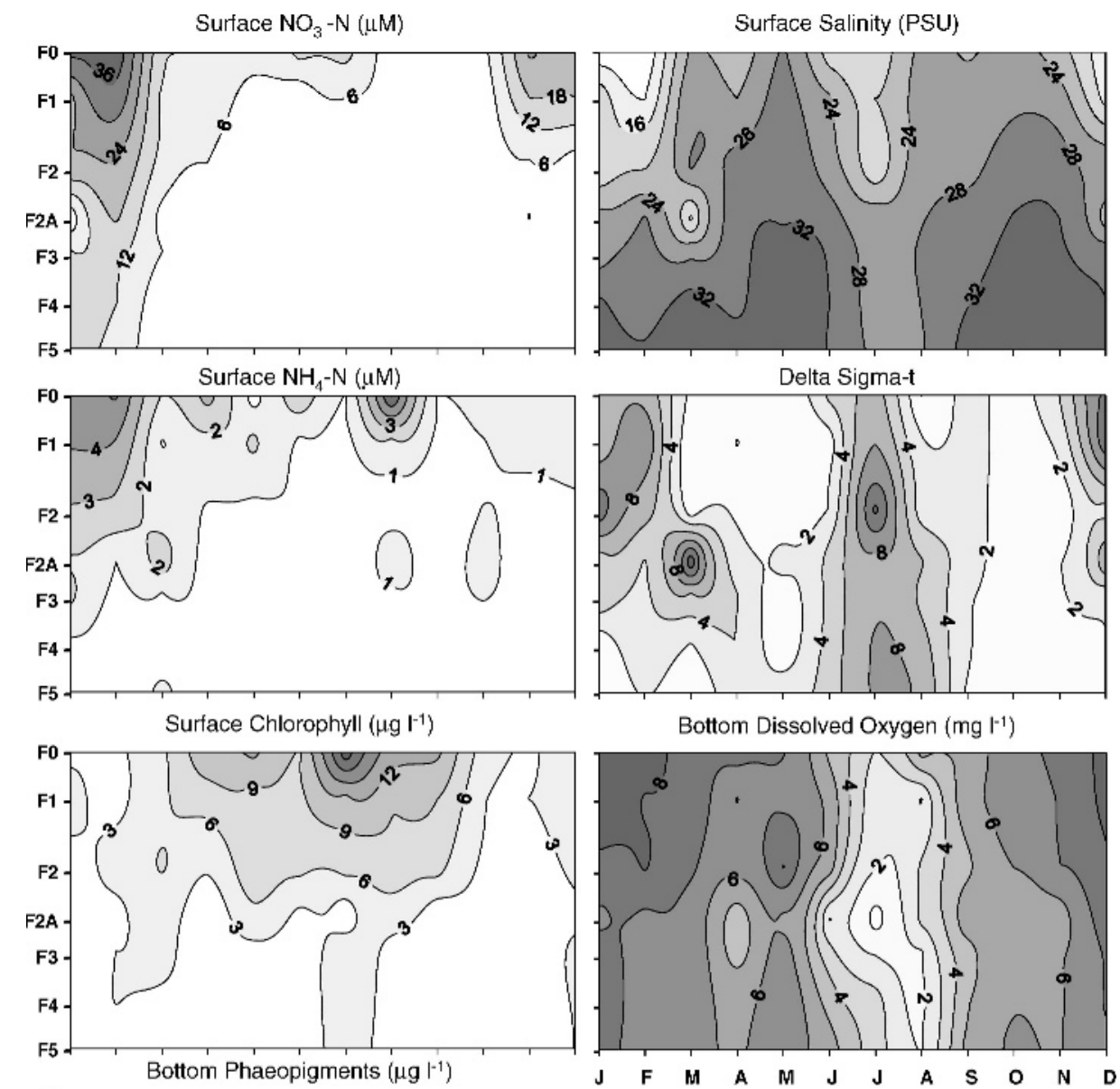

Bottom Dissolved Oxygen ( $\left.\mathrm{mg} \mathrm{l}^{-1}\right)$
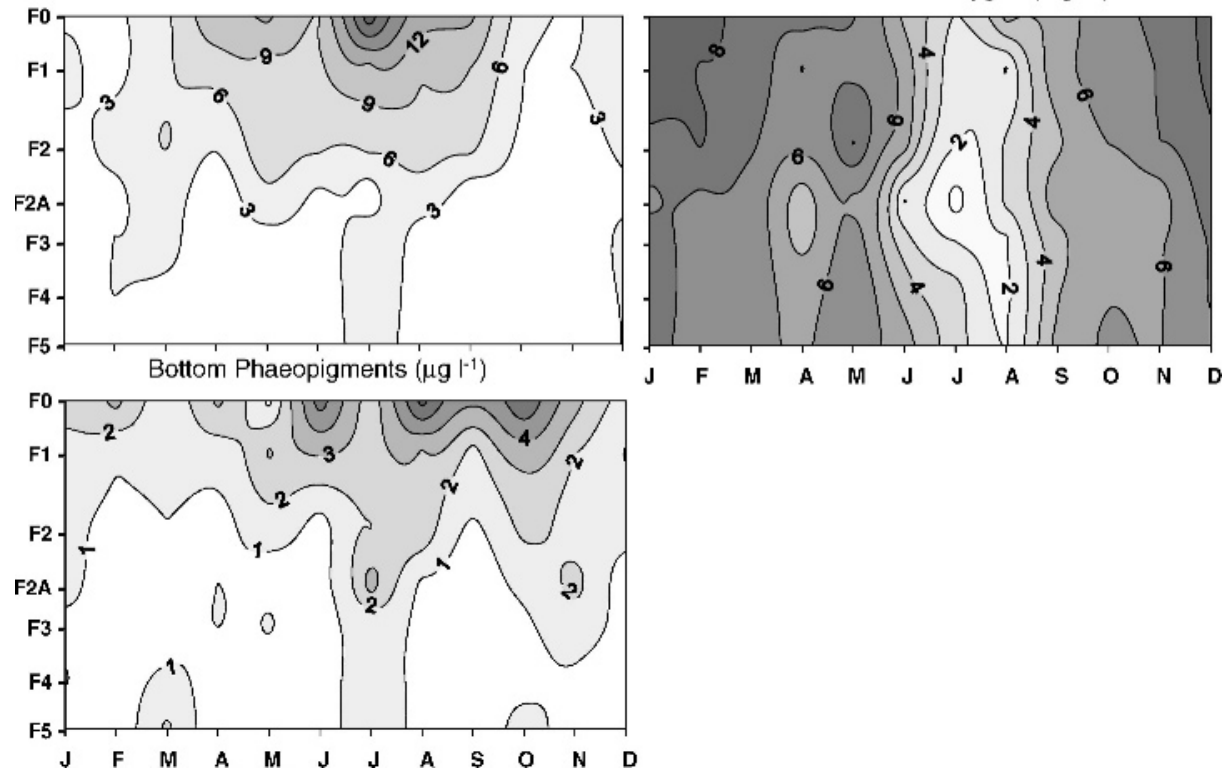

Fig. 5. Water column parameters along transect $\mathrm{F}$ (location in Fig. 2) from station F0 inshore at $5 \mathrm{~m}$ to F5 offshore $35 \mathrm{~m}$, JanuaryDecember 2001-2005. Unpublished data of Rabalais et al., Atchafalaya series.

information, and provide a good comparison of differentially affected portions of the shelf to the discharges of the Mississippi and Atchafalaya Rivers. The expression of river discharge in surface water salinity is more pronounced on transect $\mathrm{C}$ than on transect F, but each shows a spring-summer lowering of salinity across the shelf. There is an additional signal of lower winter surface salinity nearshore on transect $\mathrm{F}$, but this signal may be an artifact of the limited data set. Surface to bottom density differences along each transect reflect the seasonal freshwater inputs and more stable conditions in spring-summer.

The surface dissolved inorganic nitrogen is composed primarily of nitrate-N for both transects with high nearshore concentrations on transect $\mathrm{F}$. Ammonium-N concentrations can be high nearshore on transect F off Atchafalaya Bay. Higher concentrations of chlorophyll $a$ in surface waters on transect $\mathrm{C}$ occur after the winter-early spring peak in nitrate-N. The general pattern for transect $\mathrm{F}$ is for higher chlorophyll $a$ in surface waters nearshore to 
mid transect increasing through spring to maximal concentrations in summer to a decrease in the fall. There is a secondary peak in dissolved inorganic nitrogen in fall followed by higher chlorophyll concentrations on both transects.

The development of hypoxia along transect C occurs earlier in spring compared to transect $\mathrm{F}$ in summer (Fig. 5) and extends into September as opposed to August for transect F. Vertical profiles of oxygen concentrations along the two transects (not depicted) indicate that hypoxia takes up less of the lower water column along transect $\mathrm{F}$ than transect $\mathrm{C}$ and that hypoxia covers less of the bottom and occurs less frequently along transect $\mathrm{F}$ (Rabalais unpublished data).

The variability in the distribution of hypoxia in a cross-shelf direction can be attributed to both wind-induced cross-shelf advection or tidal advection or both (Rabalais et al. 1991, 1994; Wiseman et al. 2004). Data from an acoustic Doppler current profiler deployed in $20 \mathrm{~m}$ on transect C (Fig. 2) from mid March to mid November 2002 demonstrated the strong dominance of the alongshore currents from the east compared to cross-shelf flow (Wiseman et al. 2004). Occasionally long periods of eastward flow contrary to the expected westward flow regime were observed in May through July in 2002 and confirm observations of less saline waters across the shelf during reduced summer river discharge. The offshore cross-shelf flow during the westward flow is consistent with a wind-driven downwelling regime as would be expected under the predominantly southeasterly winds affecting the region. Intermittent periods of an upwelling favorable regime occur during winds from the north that push surface waters offshore and allow movement of bottom waters and the hypoxic water mass onshore and closer to the barrier island shore. These opposing patterns explain much of the cross-shelf variability.

\section{WEATHER-DRIVEN AND CLIMATE-DRIVEN VARIABILITY}

Conditions during extreme events such as the 1993 flood or the 1988 or 2000 droughts emphasize the importance of climate-driven river discharge and nutrient load in defining the mid-summer extent of hypoxia (Rabalais et al. 1998; Rabalais and Turner 2001). The influence of the Mississippi River system was magnified during the 1993 flood, which had above normal discharge from late spring to the fall. Flood conditions resulted in a higher flux of nutrients to the Gulf, higher concentrations of dissolved nutrients in Gulf surface waters, lower surface water salinity, higher surface water chlorophyll a biomass, increased phytoplankton abundance, greater carbon export from the surface waters (modeled), increased bottom water phaeo- pigment concentrations (an indicator of fluxed degraded surface water chlorophyll $a$ biomass), lower bottom water oxygen concentrations compared to the long-term averages for 1985-1992, and a doubled size of the hypoxic zone (Rabalais et al. 1998).

A 52-yr low-river flow of the Mississippi River occurred in 1988 (derived from data for 1988 at http://www.mvn.usace.army.mil/eng/edhd/). The discharge began at normal levels and dropped to some of the lowest levels on record during the summer months. In early June, the hydrographic conditions on the southeastern Louisiana shelf were similar to those observed in previous years, i.e., a stratified water column and some areas of oxygendeficient bottom waters. A typical seasonal sequence of nutrient-enhanced primary production and flux of organic matter in the bottom layer in the spring and led to the formation of hypoxia by early June. Density stratification was not maintained during the summer record low discharge, and low oxygen conditions were absent in the mid-July mapping cruise, except off Terrebonne Bay where local high rainfall led to stratification close to shore (Rabalais et al. 1998).

Drought conditions throughout the watershed in spring 2000 resulted in decreased discharge (derived from data for 2000 at http://www.mvn.usace. army.mil/eng/edhd/) and nutrient flux so that the typical effects of water discharge and nutrient flux on productivity, phytoplankton biomass, and carbon flux were diminished. Less productivity, coupled with windy spring weather that prevented the usual development of stratified waters, resulted in little development of hypoxia in the spring. River discharge increased and exceeded the previous 70yr average in June, and hypoxia eventually developed, although over a smaller area $\left(4,400 \mathrm{~km}^{2}\right.$; Rabalais and Turner 2001).

The influence of tropical storms and hurricanes on the distribution and size of mid-summer hypoxia was evident in the summers of 2003 and 2005. The predicted size of mid-summer hypoxia (Turner et al. 2005, 2006) was larger than the size measured during the mapping cruises, which followed severe storms. The result of tropical storms on the water column structure, mixing, and reoxygenation is evident in the bottom-water oxygen time series when a tropical storm 1,000 km away caused 3-4 m waves that led to the rapid reaeration of the bottom water (Fig. 6).

Global climate changes within the range predicted to occur in the 21st century could have profound consequences to hypoxia in the northern Gulf of Mexico (Justić et al. 2003b, 2005). A modeling study that examined the effects of global warming on the annual discharge of the 33 largest 


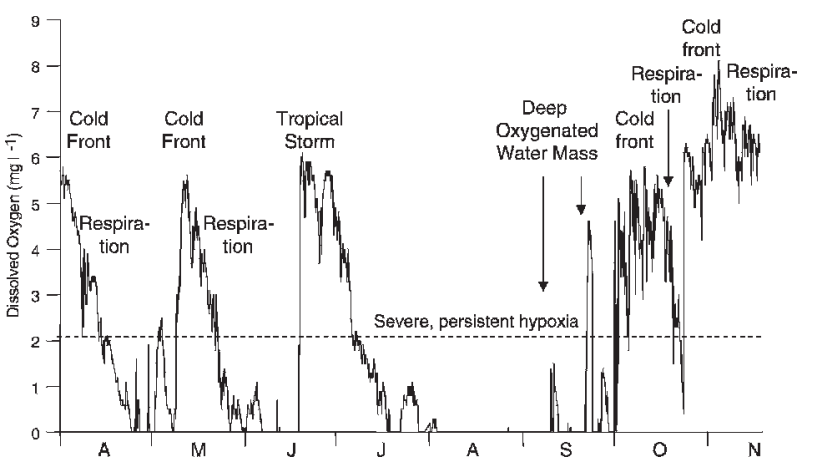

Fig. 6. Continuous bottom water dissolved oxygen in 20-m depth on the continental shelf west of the Mississippi River (April-November 1993; location in Fig. 2). The horizontal dashed line defines hypoxia. Modified from Rabalais and Turner (2006).

rivers of the world (Miller and Russell 1992) suggested that the average annual discharge of the Mississippi River would increase $20 \%$ if the concentration of atmospheric $\mathrm{CO}_{2}$ doubled. If discharge increased this much, hypoxia would intensify and expand on the Louisiana continental shelf (Justić et al. 2003a,b). Other studies have shown that the runoff estimates for the Mississippi River discharge would decrease by $30 \%$ by the year 2099 (Wolock and McCabe 1999). Whichever occurs, the increase or decrease in flow, flux of nutrients and changes in water temperature are likely to have important, but as yet not clearly identifiable, influences on hypoxia through water residence times, physical conditions, and biological processes. Increases in surface water temperature would strengthen the summer pycnocline and perhaps worsen hypoxia (Justić et al. 2003a,b), but warmer Atlantic Ocean temperatures could also increase tropical storm activity (Mann and Emanuel 2006) and their severity (Trenberth 2005; Kerr 2006).

Oxygen data collected near the bottom at a 20-m station on transect $\mathrm{C}$ (Fig. 2) demonstrate the effects of storm systems (Fig. 6). Strong mixing events of the stratified water column associated with cold fronts in spring and fall and tropical storms and hurricanes in summer result in an almost immediate increase in bottom-water oxygen levels from near anoxic to above $6 \mathrm{mg} \mathrm{l}^{-1}$. Following a mixing event and reoxygenation of bottom waters, a gradual decline of bottom oxygen concentrations driven by aerobic respiration of organic matter recommences and continues as long as the stratification is maintained. Stratification persists as long as mixing does not occur, and periods of oxygen concentrations less than $1 \mathrm{mg} \mathrm{l}^{-1}$ or near anoxia last from one-half to two months in May-September. Tidal advection of oxygenated waters is not a source of reoxygenation of bottom waters at the observing station in summer (Rabalais et al. 1994). Short-lived increases in bottom-water oxygen during summer are usually the result of intrusions of higher oxygen content water from depth during upwelling-favorable wind conditions followed by a relaxation of the winds and movement of the higher oxygen water mass offshore. Some areas of the shelf are influenced by tidal advection of oxygenated bottom water (Rabalais et al. 1994).

\section{Summary}

The temporal variability and the dimensions of hypoxia are more detailed now than the summary available in Rabalais et al. (1999, 2002b,c), but the seasonal sequence-increasing hypoxia in the spring following flux of nutrient-enhanced primary production carbon in a stratified water column, persistent and severe hypoxia in the summer, dissipation of hypoxia in the fall, and virtual absence of hypoxia in the winter-has not changed.

\section{Does ANOXIA Occur?}

Oxygen measurements near the seabed are seldom $0.0 \mathrm{mg} \mathrm{l}^{-1}$, but measurements of 0.05 $\mathrm{mg} \mathrm{l}^{-1}$ are recorded, either with instruments or Winkler titrations. While instrumentation may limit accurate detection of anoxia $\left( \pm 0.2 \mathrm{mg} \mathrm{l}^{-1}\right.$ precision), the presence of moderate $(20 \mu \mathrm{M}) \mathrm{H}_{2} \mathrm{~S}$ concentrations in bottom water indicate that the dissolved oxygen concentration is less than $0.2 \mathrm{mg} \mathrm{l}^{-1}$ and probably zero or close to it (Wong and Brewer 1977). Hydrogen sulphide concentrations up to $50 \mu \mathrm{M}$ have been measured in bottom water samples that emitted a strong odor of $\mathrm{H}_{2} \mathrm{~S}$ (Rabalais and Turner 2006; Rabalais et al. unpublished data). Hydrogen sulphide concentrations of $2-5 \mu \mathrm{M}$ have been chemically detected when there was still a faint $\mathrm{H}_{2} \mathrm{~S}$ odor. The odor of $\mathrm{H}_{2} \mathrm{~S}$ as an indicator of near anoxic or anoxic waters was evident from June through September in approximately five percent of the stations in 1985-2006 (Rabalais et al. unpublished data). $\mathrm{H}_{2} \mathrm{~S}$ poisoning of oxygen probes and tarnished silver worn by divers is assumed evidence of sulphide being present (Rabalais personal observation). Sulfur-oxidizing bacteria at the sediment-water interface have been repeatedly observed by divers and by video surveillance from remotely operated vehicles (Rabalais et al. 2001). Presence of these bacteria indicates extremely low oxygen concentrations, though not necessarily anoxia.

Oxygen consumption rates in near-bottom waters were measured during several spring and summer cruises of multiple years (Turner and Allen 1982; Turner et al. 1998; Rabalais et al. 2002b). Rates varied between 0.0008 to $0.29 \mathrm{mg} \mathrm{O}_{2} \mathrm{l}^{-1} \mathrm{~h}^{-1}$, and were sufficient to reduce the in situ oxygen 
concentration to zero in less than four weeks. The rates were inversely related to depth and decreased westward of the Mississippi River delta, consistent with the decrease in nutrients and chlorophyll $a$ concentrations in surface waters. Oxygen consumption rates calculated from continuous oxygen measurements (see below) are consistent with the findings of Turner and colleagues (in Rabalais et al. $2002 \mathrm{~b})$. If there is no mixing of the stratified layers, the period for reduction of the bottom-water oxygen concentration from about $6 \mathrm{mg} \mathrm{l}^{-1}$ to less than $2 \mathrm{mg} \mathrm{l}^{-1}$ is 18,11 , or 9 days, in April, May, and July, respectively (Rabalais unpublished data). Examples of aerobic respiratory driven declines in bottom-water oxygen derived from oxygen time series at a 20-m station on transect C (Fig. 2) are in Fig. 6.

Light conditions partially influence where hypoxic water masses are located and their severity. Light penetration has been measured on all summer hypoxia monitoring cruises since 1991 (Turner et al. unpublished data). In 1991, the 1\% light level was within $1 \mathrm{~m}$ of the bottom at $10 \%$ of the stations and within $2 \mathrm{~m}$ of the bottom at $48 \%$ of the stations. This is enough light to support photosynthesis at or near the sediment-water interface and in the water column. Enough photosynthesis may occur to compensate for respiration to the point that anoxia does not develop (Dortch et al. 1994) or that the volume of hypoxic water is reduced. A mass balance eutrophication model (Bierman et al. 1994) indicated that deeper light penetration might be more important with regard to hypoxia distribution in the western portion of the Louisiana shelf ( $>91^{\circ} \mathrm{W}$ longitude) compared to the eastern area where the water clarity is lower (either due to suspended sediments near the Mississippi River delta or shading from high algal biomass). As an indicator of the importance of light on the western shelf, the bottom-water oxygen declined in April 2005 at $29^{\circ} \mathrm{N}, 92^{\circ} \mathrm{W}$ off the Atchafalaya River at a similar rate to the April values on transect $\mathrm{C}$ (DiMarco et al. unpublished data; Rabalais et al. unpublished data), but hypoxia did not develop off the Atchafalaya River unlike the more eastern station off Terrebonne Bay where hypoxia did develop.

\section{Mississippi River Discharge AND Nutrient LOADS}

A more detailed consideration of Mississippi River flow and constituent loads is presented in Turner et al. (2007). Summarized information is presented here to compare changes in the coastal ecosystem with changes in the Mississippi River system and its contributions to the northern Gulf of Mexico.

\section{VOLUME OF Discharge}

Depending on the period of record analyzed, there are, or are not, long-term trends in the discharge of the Mississippi River. Bratkovich et al. (1994) conservatively estimated the discharge of the Mississippi River system (the sum of the discharges at Tarbert Landing [for the lower Mississippi] and Simmesport [for the Atchafalaya]) to be slightly over $19,000 \mathrm{~m}^{3} \mathrm{~s}^{-1}$ for the 1930-1997 period. Goolsby and Battaglin (2001) estimated this combined annual stream flow to be approximately 22,000 $\mathrm{m}^{3} \mathrm{~s}^{-1}$ between 1980 and 1999. Monthly average flow of the Mississippi River above the diversion point for the Atchafalaya River in spring is 25,000 to $30,000 \mathrm{~m}^{3} \mathrm{~s}^{-1}$ and decreases to below $8,500 \mathrm{~m}^{3} \mathrm{~s}^{-1}$ in August (Goolsby et al. 1999). Although flow is reduced in summer, large-scale circulation patterns facilitate the retention of the fresh water on the shelf during that period in support of continued stratification (Rabalais et al. 2002c; Wiseman et al. 2004).

There is significant interannual variability in discharge, but the 1820-1992 average (multidecadal time scale) for the Mississippi River at Vicksburg has been relatively stable near $17,000 \mathrm{~m}^{3} \mathrm{~s}^{-1}$ (Turner and Rabalais 2003; Turner et al. 2007). Bratkovich et al. (1994) examined a shorter interval of Mississippi River discharge (1900-1992) and reported that the early 1990s annual discharge rate increased by $30 \%$ from the 1950 s, but only $15 \%$ since 1900. Karl and Knight (1998) reported an increase in precipitation by about $10 \%$ across the contiguous United States between 1910 and 1997, including parts of the Mississippi River basin. To date there has not been a published analysis linking changes in Mississippi River stream flow to permanent secular climate change.

Because the amount of fresh water delivered to the northern Gulf of Mexico influences both the nutrient loads and the strength of salinity stratification on the shelf, climate-induced variability in river discharge will influence the extent and severity of hypoxia. Nitrate load increased about 300\% from the 1950 s to the mid 1990s (Goolsby et al. 1999; Goolsby and Battaglin 2001), whereas stream flow from the basin increased only $30 \%$ (Bratkovich et al. 1994). The most significant driver in the change in nitrate load is the increase in nitrate river concentration, not freshwater discharge (Justić et al. 2002). Using two different approaches, Donner et al. (2002) and Justić et al. (2002) both concluded that only $20-25 \%$ of the increased nitrate load between the mid 1960 s to the mid 1990 s was attributable to greater runoff and river discharge, with the rest due to increased nitrogen concentrations in the lower river. With nitrate concentrations in the lower 
Mississippi River remaining near $100 \mu \mathrm{M}$ since the early 1990s (Turner et al. 1998), climate-driven changes in discharge are likely to have a significant influence on the seasonal formation of and interannual variability in hypoxia in contrast to the period between 1970-1990 when nitrate concentrations were rapidly increasing. This is consistent with the results of Stow et al. (2005) who demonstrated a declining threshold for hypoxia formation as salinity stratification increased.

Similar results by Donner and Scavia (2007) indicate that climate variability could now be controlling the variability in nitrogen leaching from land and transport to the Gulf of Mexico. Agricultural land use and land cover have remained relatively constant from 1985 to 2005, and climate variability could now be controlling the precipitation amounts across the Corn Belt. The previous November-December and March-May precipitation are together a strong predictor $\left(r^{2}=0.68\right)$ of the spring nitrate flux by the Mississippi River. During a wet year, a nitrogen reduction of 50-60\%-close to twice the recommended target (Mississippi River/Gulf of Mexico Watershed Nutrient Task Force 2001)-is required to meet the goal of reducing the hypoxia zone to less than $5,000 \mathrm{~km}^{2}$.

\section{NutRIENT LOADS}

Turner and Rabalais (1991) and Justić et al. (1995) examined water quality data for the lower Mississippi River for variations in dissolved inorganic nitrogen (as nitrate), phosphorus (as total phosphorus), and silicon (as silicate). The mean annual concentration of nitrate was approximately the same in 1905-1906 and 1933-1934 as in the 1950 s, but it doubled (or tripled depending on the comparative periods) from the 1950s and 1960s values. These results were corroborated by Goolsby et al. (1999) who documented that the average mean nitrate concentration at St. Francisville during 1980-1996 was more than double the average concentration during 1955-1970. The mean annual nitrogen flux, determined by Goolsby et al. (1999) from discharge weighted regression models, approximately tripled in the 1955-1996 period with most of the increase occurring between 1970 and 1983. The increase in total nitrogen is almost entirely due to changes in nitrate concentration (Goolsby and Battaglin 2001).

The mean annual concentration of silicate in the lower Mississippi River was approximately the same in $1905-1906$ as in the early 1950 s, after which it declined by $50 \%$ (Turner and Rabalais 1991). Justić et al. (1995) documented a 30\% decrease in silicate concentration between 1960-1962 and 1981-1987. Goolsby et al. (1999) noted a $40 \%$ decline in silicate concentrations from the 1950 s to the mid-1970s when they stabilized. They further noted that there was no long-term trend in silicate load as observed for nitrate. The concentrations of nitrate and silicate appear to have stabilized since the mid 1980 s to present, but with increased variability since then (Turner et al. 1998, 2007).

There are no regular and reliable records of total phosphorus concentrations in the lower Mississippi River before 1973 and subsequent values vary greatly among years. Goolsby et al. (1999) found no longterm trend in orthophosphate or total phosphorus from 1973 to 1996. Turner and Rabalais (1991) noted a temporal change in orthophosphate consistent with increased nitrate changes, but stated that the extreme variability in the data made it unlikely that a statistical trend could be identified. Justic et al. (1995) estimated that there was a twofold increase in total phosphorus concentration, but this estimate was based on an extrapolation of a regression back to the past, rather than actual measurement.

There is agreement that nitrate concentration and flux have increased three-fold since the 1950s1960s and that levels have plateaued but exhibit considerable variability from year to year. There is also agreement that the concentration of silicate decreased, anywhere from $30 \%$ to $50 \%$ depending on the period of record, but that the load remains similar. The phosphorus data are of shorter duration, beginning in 1973, with no turn-of-thecentury or $1930 \mathrm{~s}$ data, and are less robust for determination of long-term trends, for which there is not a consensus regarding the significance and rate of change between the 1960s and 1980s.

An important management issue is the relative influence of nitrogen versus phosphorus concentrations and loads in controlling bottom-water dissolved oxygen on the Louisiana continental shelf. Model forecast results indicated a general tendency for responses to be somewhat greater for nitrogen load reductions than for phosphorus load reductions (Limno-Tech, Inc. 1995). Nitrogen is considered to be relatively more important than phosphorus in limiting primary productivity on the Louisiana inner shelf, but both phosphorus and silica may also be limiting at times and in certain locations, or combinations of nutrients may be limiting (Rabalais et al. 1999, 2002b; CENR 2000). A series of nutrient limitation or stress indicators (nutrient concentrations and ratios, alkaline phosphatase activity, phosphorus turnover times, and changes in chlorophyll $a$ enrichment bioassays [four stations]) were examined in the Mississippi River plume in March, May, July, and September of 2001 (Sylvan et al. 2006). The results indicated that phytoplankton growth at these locations was limited by phosphorus in May and July, phosphorus was weakly limiting in 
March, and nitrogen was limiting in September. The observed phosphorus limitation in May and July (Sylvan et al. 2006) is likely related to the excess nitrogen loading compared to phosphorus (see Turner et al. 2003), and both nitrogen and phosphorus management have implications for reducing hypoxia.

\section{LOnG-Term TREnds in Hypoxia: Multiple Lines OF EVIDENCE}

The Integrated Assessment concluded that "hypoxia in the northern Gulf of Mexico is caused primarily by the excess nitrogen delivered from the Mississippi-Atchafalaya Basin in combination with stratification of Gulf waters"' (CENR 2000, p. 2). This conclusion was based on an understanding of the role of nutrients in controlling the production of organic matter, the decomposition of which causes bottom-water oxygen depletion, and the documented substantial increase in the loadings of nutrients, particularly nitrate, from the rivers since the 1960s. Because there were no comprehensive, direct measurements of oxygen in the region prior to 1985 , indirect evidence of the intensification of hypoxia from the sediment record also provided support for the conclusion that regularly occurring and widespread hypoxia became a common feature of the northern Gulf shelf only after nutrient loading increased during the last half of the 20th century. Considerable additional research has been conducted since the Integrated Assessment. The results of these studies lend further credence to the conclusions of the Integrated Assessment and enrich our understanding of the long-term changes that have occurred. This new information is summarized below under five groupings of evidence.

\section{Mining OF Other Data Sets}

Rabalais et al. (1999) reviewed various reports of shelf hypoxia prior to the beginning of systematic monitoring in 1985. They noted that documented shelf hypoxia dates back to 1972 based on relatively localized and discontinuous measurements. Two recent reports examined trends in dissolved oxygen in bottom waters in data sets that began prior to 1985. Turner et al. (2005) examined an 18-yr monitoring record (1978-1995) associated with the Louisiana Offshore Oil Port (LOOP) facility located west of the Mississippi River delta and $30 \mathrm{~km}$ southeast of Belle Pass off Port Fourchon. This area generally corresponds to transect B (see Fig. 2) of the shelfwide surveys and frequently experienced summer hypoxia since those surveys began in 1978. Dissolved oxygen concentrations during June, July, and August were rarely hypoxic $\left(<2 \mathrm{mg} \mathrm{l}^{-1}\right)$ prior

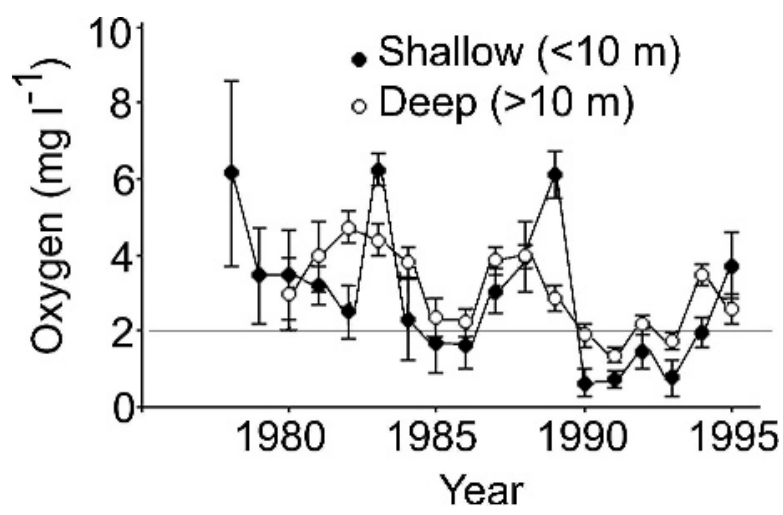

Fig. 7. Bottom water oxygen concentration $\left(\mathrm{mg} \mathrm{l}^{-1}\right)$ for shallow and deep water stations for June, July, and August (mean \pm 1 standard error); from Turner et al. (2005).

to 1984, but frequently hypoxic after that time (Fig. 7). Using the relationship between total Kjeldahl nitrogen (TKN, largely organic nitrogen) measured at the LOOP stations and the shelfwide area of hypoxia between 1985 and 1995, and the relationship between TKN at the LOOP stations and Mississippi River spring nitrate flux, Turner et al. (2005, p. 76) hindcasted that there would have been "no substantial hypoxia" on the Louisiana shelf before the 1970s when river nitrate flux began to rise.

Stow et al. (2005) examined water quality data from the Southeast Area Monitoring and Assessment Program (SEAMAP) fisheries-independent trawl surveys conducted from 1982 to 2002 over the Louisiana shelf $(<50 \mathrm{~m}$ depth). They used a general additive model to fit the trend of declining bottom dissolved oxygen on the Louisiana shelf during this period. They found that the difference of surface and bottom salinity (influencing density stratification) is an important predictor of hypoxia, exhibiting a threshold, where the probability of hypoxia increases rapidly at approximately $4.1 \mathrm{psu}$. Using a Bayesian change-point model, they showed that this stratification threshold decreased from 1982 to 2002, indicating the degree of stratification needed to induce hypoxia has decreased, implicating a long-term factor or factors transcending flow-induced stratification differences. Stow et al. (2005) did not specifically address the influence of increased nitrate loading on the declining threshold, but pointed out other factors, including increasing surface temperature (and its influence on oxygen solubility) could also play a role.

\section{Statistical AnAlyses}

There are many challenges in discerning the influence of various inputs from the Mississippi and 
Atchafalaya Rivers, including fresh water, nutrients, and other materials, on the development of hypoxia because they strongly covary with river flow (Turner et al. 2006). The two studies just reviewed (Stow et al. 2005; Turner et al. 2005) add further evidence that, while freshwater inflows and their influence on density stratification are an important determinant of bottom oxygen depletion, other factors influence the long-term increase in hypoxia. Turner et al. (2006) performed statistical analyses to discern the relative strengths of the loading of various forms of nitrogen, phosphorus, dissolved silicate, and their molar ratios on the variance in the size of the summertime low oxygen zone. A stable multiple regression that included as variables Year and river nitrate + nitrite loading for the two months prior to the measurement of the hypoxic zone described $82 \%$ of variation in the size of the hypoxic zone from 1978 to 2004 [y $\left(\mathrm{km}^{2}\right)=-1337953.4+$ $672.1589 *$ Year $+0.0998 *($ May flux as nitrite + nitrate), Turner et al. 2006, p. 145 ]. The inclusion of the time variable Year is consistent with the documented increase in carbon stored in sediments after the 1970s (Rabalais et al. 2004; Turner et al. 2004). The variable Year is also negatively correlated with the total nitrogen:total phosphorus ratio (currently fluctuating around 20:1) in a way that suggests nitrogen, not phosphorus, has become more important as a factor limiting phytoplankton growth in the last $20 \mathrm{yr}$. Nitrogen (specifically nitrate + nitrite) not phosphorus, dissolved silicate, or their molar ratios, appears to be the major driving factor influencing the size of the hypoxic zone on this shelf. Hind casting this relationship also lends credence to the limited observational and historical sediment record that hypoxia was limited in extent in the early 1970s.

\section{Models}

The Integrated Assessment (CENR 2000) relied on a relatively simple mass balance model (Bierman et al. 1994; in the CENR Topic 4 report by Brezonik et al. 1999) to forecast the responses of dissolved oxygen and chlorophyll concentrations to reductions of nitrogen and phosphorus loadings. The model simulated summer steady-state, three-dimensional, food-web-nutrient-oxygen dynamics and is further discussed by Bierman et al. (2003). Justić et al. (2002, 2003b) developed a model that simulates two-layer, time-dependent, oxygen dynamics for one location off the Louisiana coast. This model is driven by meteorological conditions and nitrogen loads. Model forcing functions include monthly values of the Mississippi River runoff, nitrate concentration, nitrate flux, ambient water column temperature, and surface winds. Scavia et al. (2003) published a model that simulates summer steady- state, one-dimensional horizontal dynamics of nutrient-dependent production, respiration of organic matter, and resulting oxygen balance. It is driven by May-June total nitrogen loads, calibrated to $17 \mathrm{yr}$ of data between 1985 and 2002, and was used to simulate, hindcast, and forecast hypoxic zone length and area in response to changes in nitrogen loads. The model simulates concentrations of subpycnocline oxygen-consuming organic matter and dissolved oxygen downstream from the Mississippi and Atchafalaya rivers.

The three modeling approaches (referred to here as the Bierman, Justić, and Scavia models) capture very different aspects of the physics, chemistry, biology, and ecology of the northern Gulf. These models were compared in a collaborative paper (Scavia et al. 2004). One question they addressed was: when did large-scale hypoxia start in the Gulf of Mexico? Hindcasts of the areal extent of hypoxia by the Scavia model suggest that large hypoxic regions were not likely to have occurred prior to the mid 1970 s and that the size of those regions grew between the mid 1980s and have since fluctuated. Hindcasts of subpycnocline oxygen concentrations by the Justic model suggest that subpycnocline summer-minimum oxygen concentrations offshore of Terrebonne Bay were fairly constant at approximately $6 \mathrm{mg} \mathrm{l}^{-1}$ between 1955 and 1969, decreased during the 1970s, and consistently dropped below $2 \mathrm{mg} \mathrm{l}^{-1}$ in most years since 1978. Scavia et al. (2004) concluded that, taken together, their models suggest that large-scale regions of hypoxia were not likely to be present prior to the $1970 \mathrm{~s}$, similar to the results of Turner et al. (2005, 2006).

\section{New Studies of the Sediment Record}

Indicators of increased biological production and decreased oxygen availability in the sediment record provide information to support the conclusion that hypoxia intensified in the last half of the 20th century as a result of increased nutrient loading (Rabalais et al. 1996, 2002a, 2007; CENR 2000). These indicators included increased accumulation of organic matter and biogenic silica in sediment deposits (reflecting increased primary production and diatom production) and increased glauconite (a mineral indicative of reducing environments) as a percentage of coarse-grained sediments, decreased diversity of ostracods and benthic foraminiferans, and changes in the species composition of benthic foraminiferans (all indicative of depleted oxygen conditions). These trends show that, while there are signs of increased production and oxygen depletion earlier in the 20th century, the most dramatic changes have occurred since the 1960s. Most of this information came from sediment cores taken from depositional environments in the 
Louisiana Bight, west of Southwest Pass. These historical data analyses are useful for assessing the time course of increased frequency and intensity of hypoxia in the Louisiana Bight. There are few netdepositional areas farther west along the shelf that yield a fairly undisturbed sediment record. Limited core data from the western Louisiana shelf (Fig. 2) include similar patterns of increasing carbon, diatom remains as biogenic silica, and chloropigment storage with time, but there are, as yet, no data on shifts in oxygen deficiency (Rabalais et al. 2004; Turner et al. 2004).

Microfossils and other biomarkers have been used by several workers as paleohypoxia tracers on the Louisiana shelf. A benthic foraminiferal diversity reduction in the Louisiana Bight is documented by Shannon-Wiener Diversity Index data of Nelsen et al. (1994) and Platon et al. (2005), and also by species richness data of Platon et al. (2005). Species diversity measures differ at different core sites or water depths, but most show a reduction beginning in the early 1950s. Relative abundances of agglutinated and porcelaneous groups of Foraminifera declined conspicuously in the 20th century (Platon et al. 2005). The well-known porcelaneous genus Quinqueloculina was a noticeable member of the fauna from 1700 to 1900 (Rabalais et al. 1996), but it has almost disappeared from parts of the Louisiana Bight in the past 50 or $60 \mathrm{yr}$ (Platon et al. 2005). The abundances of several hyaline species have also declined in the past century (Platon et al. 2005). In contrast, the relative abundance of Buliminella morgani, a hypoxia-tolerant endemic species of the Gulf of Mexico, has increased markedly in recent decades, and the species now dominates the benthic foraminiferal community $(>50 \%)$ within areas of chronic seasonal hypoxia (Blackwelder et al. 1996; Rabalais et al. 2000; Platon and Sen Gupta 2001). Osterman et al. (2005) suggest that the percentage of B. morgani, when combined with those of two other hypoxia tolerant species, Pseudononion atlanticum and Epistominella vitrea, serves as a measure (the PEB index) that can be used to identify low-oxygen events in the Louisiana Bight. Overall, an increasing trend of the PEB index agrees with earlier reports that hypoxia has worsened in the past $50 \mathrm{yr}$ (Osterman et al. 2005).

The hypoxia proxy that has drawn most attention in Gulf of Mexico foraminiferal studies is a simple index based on the abundances of Ammonia and Elphidium (the A-E index), two common coastal genera. The index is trusted as a relative measure of past hypoxia because observed values correlate with sedimentary organic content (Sen Gupta et al. 1996) and bottom-water $\mathrm{O}_{2}$ concentrations (Thomas et al. 2000), and live individuals of Ammonia, but not of Elphidium, have been found in anoxic or nearly-anoxic waters (Platon and Sen Gupta 2001). Elphidium is not intolerant of hypoxia, but Ammonia is more tolerant, so that the A-E index rises as hypoxia worsens. In the Louisiana Bight, A-E indices from multiple cores (Rabalais et al. 1996; Sen Gupta et al. 1996; Platon and Sen Gupta 2001) show that oxygen stress increased (in intensity or duration) over much of the 20th century, and especially in the last half century. Using the A-E index and the PEB index, Brunner et al. (2006) inferred occurrence of hypoxia south of the Mississippi-Alabama barrier islands beginning in the 1950s. The A-E index has also proven to be a strong, consistent oxygen-stress signal in the Chesapeake Bay (Karlsen et al. 2000) and Long Island Sound (Thomas et al. 2000).

Paleoindicator studies of phytoplankton production and pigments continue to support prior conclusions of long-term changes in the coastal ecosystem. Turner et al. (2004) observed increases in the accumulation of biogenic silica in cores collected in a number of locations in the Louisiana Bight with the most marked increases beginning in the 1960s. Parsons et al. (2002) reported a pronounced increase in the abundance of diatoms of the genus Pseudo-nitzschia, a lightly-silicified species, in sediments deposited after 1960 as the nitratenitrogen load increased and the silicon:nitrogen ratio decreased.

Phytoplankton pigments deposited in sediments reflect not only the composition of the phytoplankton, with some pigments being specific to certain algal or cyanobacterial taxa, but also reflect oxygen availability at the seabed, because oxygen affects the degree of pigment decomposition. In the Louisiana Bight, Rabalais et al. (2004) found a general increase in accumulation of chlorophyll $a$, phaeopigments, zeaxanthin, fucoxanthin, and most carotenoids over time, with a gradual change from 1955 to 1970 , followed by a fairly steady increase to 1997 . The highest chloropigment concentrations were found in cores likely to be exposed to seasonal hypoxia, which reduces pigment breakdown. Interestingly, in one core taken on the inner shelf off southwestern Louisiana (Fig. 2), this increase in chloropigment accumulation appeared to occur later, in the 1990s. Other pigment biomarkers reflect the presence of phototrophic bacteria that live under oxygen-poor conditions. Chen et al. (2001) found that the downcore distribution of bacteriopheophytin- $e$ and bacteriopheophytin- $e$ homologues indicated the highest concentrations occurred in sediments deposited since 1960. These bacteriopigments were not detected prior to the early 1900s. These results are consistent with the lack of hypoxia intolerant foraminiferans after 1900, and reinforce the evidence that hypoxia was not 
a feature of the continental shelf west of the Mississippi River delta prior to the beginning of the 20th century.

The accumulated body of evidence from fossil and chemical biomarkers in the Louisiana Bight shows trends of increased primary production in the last half of the 20th century that was accompanied by more severe or persistent hypoxia beginning approximately in the 1960s. Limited core data from the western Louisiana shelf (Rabalais et al. 2004; Turner et al. 2004), coupled with the model results of Scavia et al. (2003), suggest that hypoxia developed there somewhat later during the 1980s and 1990s.

\section{Coherence with Other Hypoxic Areas}

Several global syntheses of hypoxia and eutrophication have been published since completion of the Integrated Assessment (CENR 2000). Diaz (2001) and Diaz et al. (2004) updated the synthesis of Diaz and Rosenberg (1995) on marine benthic hypoxia and increased, once again, the number of documented coastal areas of hypoxia and worsening hypoxia in half the studies cited. Cloern (2001) published a conceptual model of coastal eutrophication along with many examples. Rabalais (2004) presented many examples of increased nutrient loading (nitrogen and phosphorus), increased primary production, loss of macrovegetation, increased incidence of harmful algal blooms, and increased hypoxia in several coastal ocean systems since 1960. Boesch (2002) added to Cloern's inventory and bracketed when the changes in these eutrophying coastal ecosystems began. In almost all cases, the tipping points fell within a 20 -yr period between 1960 and 1980, a period during which there was a dramatic increase in the amount of fixed nitrogen being added to the biosphere, mainly from industrially fixed fertilizers (Galloway and Cowling 2002)

An analogous situation to the Louisiana shelf is the northwestern shelf of the Black Sea, because it too is an exposed shelf rather than an enclosed embayment, and it is fed by large rivers. Bottomwater hypoxia on the northwestern shelf of the Black Sea was first documented in 1973 (Zaitsev 1992). There is substantial evidence that eutrophication in the Black Sea is the result of large increases in the discharge of nitrogen and phosphorus to the Black Sea from the 1960s and 1970s (Mee 2001). The typical scenario followed with increased nutrients triggering dense phytoplankton blooms, a decrease in seawater transparency and an increase in the load of organic detritus reaching the seafloor (Tolmazin 1985; Mee 1992, 2001; Zaitsev 1992). The high organic loading was followed by an expansion of oxygen-deficient waters over the northwestern shelf in depths of 8 to $40 \mathrm{~m}$ and over areas of the seafloor covering up to $40,000 \mathrm{~km}^{2}$. As a result of the dissolution of the former Soviet Union and declines in subsidies for fertilizers, the decade of the 1990s witnessed a substantially decreased input of nutrients to the Black Sea (Mee 2001; Lancelot et al. 2002). For the first time in several decades oxygen deficiency was absent from the northwestern shelf of the Black Sea in 1996, and receded to an area less than $1,000 \mathrm{~km}^{2}$ in 1999 (Mee 2001). Just when Black Sea researchers were convinced that the northwestern shelf was moving towards recovery, late rainfall and higher temperatures triggered a new large-scale hypoxic event in 2001, endangering the slow recovery of the coastal ecosystem (Mee et al. 2005). Some think that the inclusion of many central and eastern European countries in the European Union will trigger economic and industrial growth and modernized agriculture that could threaten Black Sea coastal water quality, but membership in the European Union will also bring common policies and regulations that will protect aquatic resources.

Parallel developments coincident with increased nutrient loading in other ecosystems present further compelling evidence, in addition to extensive observational, historical, and mechanistic evidence, that hypoxia in the northern Gulf of Mexico became a severe and recurrent stress in this ecosystem after the $1960 \mathrm{~s}$ because of a rise in nutrient loading at that time.

\section{Alternative Causes}

There are alternative hypotheses to explain why hypoxic conditions in the Gulf of Mexico occur or have worsened. Some issues were addressed in the Integrated Assessment (e.g., upwelling; CENR 2000). Others put forward are addressed here with regard to the overwhelming influence of the Mississippi-Atchafalaya inputs as well as the timing of landscape and coastal ecosystem changes.

\section{Channeling and Direction of Flow}

In addition to the intensification of agriculture and steady population increase within the Mississippi basin, human activities have changed the natural functioning of the Mississippi River system in many other ways (Turner and Rabalais 2003). Dams, navigation, channelization, and flood control through leveeing along the length of the river are clearly important watershed alterations that affect the delivery of water, dissolved and particulate matter, and the uptake and transformation of nutrients. Other significant alterations in landscape (e.g., deforestation, conversion of wetlands to cropland, loss of riparian zones, loss of bottomland 
hardwood flood plains, and expansion of artificial agricultural drainage) have affected both the timing of runoff, especially the peaks, and trapping of sediments and nutrients. In particular, the dramatic proliferation of agricultural land under artificial drainage during the 20th century (Mitsch et al. 2001) interacted with increased fertilizer applications in the later half of the century to result in high rates of nitrate losses.

For the most part, the structural hydrological changes affecting the river occurred prior to the 1960 s and prior to the advent of increased nutrient concentrations and loads and recurrent hypoxia on the shelf. Levees that extended down the lower Mississippi River almost to the distributary channels were present since the 1860 s but were heightened and reinforced following the 1927 flood. Flows down the Atchafalaya had gradually grown to present day levels after massive log rafts were cleared in 1860, such that the proportion of the Mississippi and Red River flows that had been captured either equaled or exceeded the presently regulated flow well before the completion and operation of the Old River Control Structure at river mile 315 in 1962 (Reuss 1998). The Old River Control Structure was built to prevent the Atchafalaya River from capturing the main flow of the Mississippi River. The present amount of water (since the 1973 flood) diverted from the Mississippi River to the Atchalafaya River, when combined with the flow of the Red River going into the Atchafalaya River, is $30 \%$ of the total flow of the Mississippi River at the point of diversion.

Actions taken to manage the distribution of river flow through the Mississippi-Atchafalaya delta in the future could be of major consequence to the development and distribution of hypoxia on the continental shelf. Effects of river redistribution should be taken into account in integrated ecosystem-based management approaches that address both coastal wetland loss and hypoxia (Boesch 2006). River diversions contemplated to restore wetlands could affect some degree of nutrient trapping, although the amount of nitrate that would be lost or converted even in the most ambitious efforts would be only a small part of the nutrient reduction requirements of the Action Plan (Mitsch et al. 2001). Management decisions that direct more flow from Southwest Pass, presently a major conduit to the shelf edge, onto the inner shelf either to the east or west of the birdfoot delta, or that increase the flows down the Atchafalaya may have major consequences for shelf hypoxia. Most occurrences of hypoxia east of the Mississippi River are during periods of high Mississippi River flow (Rabalais 1992) and would increase if flow were directed to this area; more fresh water and nutrients delivered to shallow water west of the birdfoot delta would intensify stratification and nutrient-enhanced production there; and historic sediment data down plume of the Atchafalaya outflow indicate that primary production has increased and hypoxia worsened (Rabalais et al. 2004; Turner et al. 2004) as more lower Mississippi River water was shifted through the Old River Control Structure and onto the western Louisiana shelf.

\section{Other Nutrient or Carbon Sources}

The Mississippi River also delivers a complement of different nitrogen and carbon forms in the dissolved phase as well as particulate matter (Turner et al. 2007). Recent estimates of the dissolved organic carbon loading to the Gulf of Mexico is $3.1 \times 10^{3} \mathrm{Pg} \mathrm{yr}^{-1}$ (Bianchi et al. 2004) and is $0.80 \times$ $10^{9} \mathrm{~kg} \mathrm{yr}^{-1}$ for particulate organic carbon and 0.078 $\times 10^{9} \mathrm{~kg} \mathrm{yr}^{-1}$ for particulate nitrogen (Duan and Bianchi 2006). The estimate for particulate organic carbon is within the range of previous estimates $(8.0$ $\times 10^{9} \mathrm{~kg} \mathrm{C} \mathrm{yr}{ }^{-1}$, Milliman and Meade 1983; $2.5 \times$ $10^{9} \mathrm{~kg} \mathrm{C} \mathrm{yr}^{-1}$, Trefry et al. 1994; $0.21 \times 10^{9} \mathrm{~kg} \mathrm{~N}$ $\mathrm{yr}^{-1}$, Goolsby 2000). A potential carbon or nitrogen source from eroding wetlands appears to be relatively small compared to the river-derived carbon or nitrogen loading spread out over the same continental shelf (Turner et al. 2007). Evidence from stable carbon isotopes (Turner and Rabalais 1994) indicated that the marsh signal is very close to shore and that the terrestrial river carbon signature remains close to the Mississippi River delta. The overwhelming signature on the continental shelf affected by hypoxia is from in situ produced marine carbon (Turner and Rabalais 1994). Continued increase in knowledge of the biological importance of constituents, such as dissolved organic phosphorus and urea (Dyhrman and Ruttenberg 2006; Glibert et al. 2006), particularly within the lower salinity, higher suspended sediment portion of the river plumes, dictate increased need to monitor these constituents.

The direct atmospheric deposition to the offshore surface waters is a small amount of the total nitrogen budget (1-2\%, Goolsby et al. 1999). Upwelled flow of nitrate from deeper waters may be important at the shelf edge at depths of $100 \mathrm{~m}$, but there are limited physical transport mechanisms for enhancing continental shelf processes (Wiseman et al. 2004) and no documented role for it in controlling the severity or size of the hypoxic zone. Groundwater discharges directly to the Gulf are unlikely to be important because of the lack of shallow aquifers along the Louisiana coast and the low potential for transfer in a cross-shelf direction (Wiseman et al. 2004). Saline groundwater seeps through bottom sediments on the inner to mid 
Louisiana shelf, but the source and composition of this groundwater is uncertain (Krest et al. 1999). Another study indicates that oil and gas formation water, geothermal convection, and seawater recirculation are the major sources of ground water on the Louisiana shelf, with a minimum input of terrestrially derived topography driven flow (McCoy et al. 2007).

The best current knowledge, confirming the Integrated Assessment (CENR 2000), is that the outflows of the Mississippi and Atchafalaya rivers dominate the nutrient loads to the continental shelf where hypoxia is likely to develop.

\section{Metrics OF HyPOXIA}

Obtaining the data necessary to determine the size of mid-summer hypoxia with regard to the goal of the Action Plan (Mississippi River/Gulf of Mexico Watershed Nutrient Task Force 2001) requires at least one quasi-synoptic survey in mid to late July to be consistent with the long-term data (Rabalais et al. 1999, 2002a, unpublished data). Additional surveys in June, July, August, and September would enhance our understanding of temporal variability in the distribution of hypoxia. If additional surveys were to be incorporated into a future monitoring program, additional metrics that consider the increased variability likely to be observed would need to be developed.

Alternative metrics, other than bottom area, can be used to quantify the extent, duration, and intensity of hypoxia. Volume measurements are typically used in the Chesapeake Bay to measure change and to develop empirical relationships with river discharge (e.g., Hagy et al. 2004). Preliminary volume calculations for the northern Gulf of Mexico hypoxic zone correlate well with bottomarea estimates $\left(\left[\right.\right.$ volume $\left(10^{9} \mathrm{~m}^{3}\right)=0.0041$ (area in $\left.\left.\mathrm{km}^{2}\right)-13.727, \mathrm{r}^{2}=0.7391, \mathrm{n}=14\right]$, Rabalais et al. unpublished data). The average hypoxic volume for the northern Gulf of Mexico $\left(45 \times 10^{9} \mathrm{~m}^{3}\right)$ is about an order of magnitude greater than the average hypoxic volume for the Chesapeake Bay; the Gulf of Mexico approached $10^{11} \mathrm{~m}^{3}$ in 2002.

Area or volume estimates of dissolved oxygen concentrations less than a certain value (e.g., $<2$ $\mathrm{mg}^{-1}$, moderate hypoxia, and $<1 \mathrm{mg} \mathrm{l}^{-1}$, severe hypoxia) do not adequately describe the total oxygen deficiency of the water column. Dissolved oxygen condition can be determined as a deficit (or a surplus) of oxygen below (or above) $100 \%$ saturation at a known temperature and salinity (Justić 1991). Calculations of oxygen deficiency would be useful in models that link oxygen budgets with nutrient loads and carbon budgets. Changes in nutrient management that can be expressed in altered loads of nitrogen and phosphorus and subsequent changes in carbon and oxygen budgets provide a more comprehensive status of ecosystem condition than area or volume calculations.

Other nutrient management strategies identify ecological goals to determine steps to achieve those goals. The Tampa Bay National Estuary Program set a goal of increase in percent cover of turtle grass, Thalassia testudinum, and other native seagrasses in Tampa Bay over a 20-yr period (summarized in National Research Council 2000). Nitrogen loading reductions (tons per year) were proposed that would lead to a specified improved level of water clarity (by reducing phytoplankton biomass) that was needed to achieve the desired increased area of seagrasses. The New York State Department of Environmental Conservation, besides mapping area of dissolved oxygen levels, determines the weekly bottom-water oxygen levels, and from that determines the number of days of hypoxia $\left(<3.5 \mathrm{mg} \mathrm{l}^{-1}\right)$ each year. Length or frequency of oxygen concentrations below a specified level is used to characterize a degraded ecological condition (National Research Council 2000), and indices can be developed for quantifying hypoxia and anoxia (Nürnberg 2004). Other restoration or management strategies determine swimable, fishable, drinkable standards for water use or levels of dissolved oxygen below which specific organisms are physiologically stressed, die, or are unable to sustain healthy population levels.

The current method of assessing the mid-summer extent of hypoxia is sufficient to support the Action Plan in assessing whether the five-year running average of the hypoxic area is less than $5,000 \mathrm{~km}^{2}$. It also has the advantage that it reflects the early history of research in the area, can be consistently acquired, and addresses the public interest of how large the Dead Zone is. More frequent measurements of simple metrics (e.g., area and volume) from late spring through late summer would help ensure that the metric is representative of the system in any given year. A series of years with active tropical storm seasons may skew the area or volume data to less than representative of the river discharge, nutrient flux, and conditions of stratification, such as when the water column is disrupted by a storm within a week or two of the mapping survey (e.g., 2003 and 2005). Such a misrepresentation of the annual cycle of hypoxia formation and maintenance could negatively influence management plans for reducing shelf hypoxia and undercut public support for management.

Metrics associated with the monthly (transect C west of the Mississippi River) and bimonthly (transect F off the Atchafalaya River; Figs. 4 and 5) transects and coastal observing systems at fixed points (Fig. 2) continue to provide greater temporal 
resolution to the physical, chemical, and biological properties associated with hypoxia and the discharges of fresh water and associated constituents from the Mississippi and Atchafalaya rivers. Higher resolution measurements with towed instrumentation or autonomous underwater vehicles, while not addressing the metrics necessary to determine the efficacy of the Action Plan, should be considered in future research to facilitate understanding of the dynamics of Gulf hypoxia and to enhance model development and validation.

\section{Conclusions}

The details of the variability and dimensions of hypoxia are more fully described now than when compiled for the Integrated Assessment (CENR 2000), but the time course of development of hypoxia and its seasonal and spatial distribution have not changed. The quasi-synoptic, shelfwide mapping of the hypoxic area and the associated biological, chemical, and physical variables on a consistent grid in mid summer is an adequate and valuable means of measuring hypoxic condition in support of the 2001 Action Plan. Increased coverage of hypoxia shelfwide distributions during summer months would provide complementary data on summer distribution and compensatory data to account for precruise events in years when the consistent mid-summer grid follows storms. Finer resolution of features, more frequent surveys over shelf-scale areas, and high frequency observations at key locations across the shelf are needed to better understand the biological, chemical, and physical processes that support the formation and maintenance of hypoxia.

Other metrics of hypoxic condition, such as volume and total oxygen deficiency, which can be constructed using existing data and future data, will provide additional insight into hypoxia dynamics. Hypoxic area has the advantages of being relatively simple to calculate, is a long-term indicator, and is a measure that is readily grasped by the public. For longer-term indication of ecosystem response to changes in nutrient loads (anthropogenic increases, managed reductions, or climate-induced changes), a fairly simple expression of the extent and severity of hypoxia would benefit the public discourse on remediation and prevention. Additional considerations for more detailed indices of hypoxia are the cost, the degree of complexity, and a continued consistent collection of the data that support the indicator.

The causes of hypoxia formation, size and severity, and changes over decadal scales, with variations in Mississippi River discharge and nutrient loads, are reinforced by additional data and published results summarized in this paper. The long-term data on hypoxia, sources of nutrients, associated biological parameters, and paleoindicators continue to verify and strengthen the relationship between the nitrate-nitrogen load of the Mississippi River, the extent of hypoxia, and changes in the coastal ecosystem (eutrophication and worsening hypoxia) that reflect the increased nitrogen loads. Additional results on phosphorus and nitrogen limitation in the Mississippi River plume (four cruises in 2001; Sylvan et al. 2006) add to the existing body of evidence that nutrient limitation varies by season, location, and salinity (Rabalais et al. 2002b) and indicate that both nitrogen and phosphorus, which derive primarily from nonpoint sources (Goolsby et al. 1999), should be addressed in future nutrient management plans. Multiple lines of evidence, representing a wide array of data sources, provide a consistent big-picture scenario of increased eutrophication resulting from increased nutrient loading and manifesting as a seasonal and perennial hypoxic zone. The additional findings broadly reinforce the science supporting the 2001 Action Plan that aims to reduce nutrient loads, primarily nitrogen, as a means of reducing hypoxia in the northern Gulf of Mexico.

\section{ACKNOWLEDGMENTS}

We thank the many people who have helped collect data in the last three decades, A. Sapp and B. Cole for many of the figures, and the National Oceanic and Atmospheric Administration, Center for Sponsored Coastal Ocean Research grant number NA03NOS478003 to Louisiana Universities Marine Consortium for the preparation of this manuscript.

\section{Literature Cited}

Bianchi, T. S., T. Filley, K. Dria, And P. G. Hatcher. 2004. Temporal variability in sources of dissolved organic carbon in the lower Mississippi river. Geochmicia et Cosmochimica Acta 68: 959-967.

Bierman, JR., V. J., S. C. Hinz, D. Zhu, W. J. Wiseman, JR., N. N. RABalais, AND R. E. Turner. 1994. A preliminary mass balance model of primary productivity and dissolved oxygen in the Mississippi River plume/inner Gulf Shelf region. Estuaries 17: 886-899.

Bierman, JR., V. J., S. C. Hinz, D. Zhu, W. J. Wiseman, JR., N. N. Rabalais, AND R. E. TURner. 2003. Forecasting hypoxia in the Gulf of Mexico: Responses to nutrient loadings from the Mississippi River Basin, p. 91-96. In N. J. Valette-Silver and D. Scavia (eds.), Ecological Forecasting: New Tools for Coastal and Ecosystem Management. NOAA Technical Memorandum NOS NCCOS 1. NOAA Coastal Ocean Program, Silver Spring, Maryland.

Blackwelder, P., T. Hood, C. Alvarez-Zarikian, T. A. Nelsen, AND B. A. MCKEE. 1996. Benthic Foraminifera from the NECOP study area impacted by the Mississippi River plume and seasonal hypoxia. Quaternary International 31:19-36.

Boesch, D. F. 2002. Challenges and opportunities for science in reducing nutrient over-enrichment of coastal ecosystems. Estuaries 25:744-758.

Boesch, D. F. 2006. Scientific requirements for ecosystem-based management in the restoration of Chesapeake Bay and Coastal Louisiana. Ecological Engineering 26:6-26. 
Bratkovich, A., S. P. Dinnel, And D. A. Goolsby. 1994. Variability and prediction of freshwater and nitrate fluxes for the Louisiana-Texas shelf: Mississippi and Atchafalaya River source functions. Estuaries 17:766-778.

Brezonik, P. L., V. J. Bierman JR., R. Alexander, J. Anderson, J. Barko, M. Dortch, L. Hatch, G. L. Hitchcock, D. Keeney, D. Mulla, V. Smith, C. Walker, T. Whitledge, and W. J. Wiseman JR. 1999. Effects of Reducing Nutrient Loads to Surface Waters within the Mississippi River Basin and the Gulf of Mexico, Topic 4 Report for the Integrated Assessment on Hypoxia in the Gulf of Mexico. NOAA Coastal Ocean Program Decision Analysis Series 18. NOAA Coastal Ocean Program, Silver Spring, Maryland.

Brunner, C. A., J. M. Beall, S. J. Bentley, and Y. Furukawa. 2006. Hypoxia hotspots in the Mississippi Bight. Journal of Foraminiferal Research 36:95-107.

Chen, N., T. S. Bianchi, B. A. McKee, and J. M. Bland. 2001. Historical trends of hypoxia on the Louisiana shelf: Applications of pigments as biomarkers. Organic Geochemistry 32:543561.

Cloern, J. E. 2001. Review. Our evolving conceptual model of the coastal eutrophication problem. Marine Ecology Progress Series 210:223-253.

Committee on Environment and NAtural Resources (CENR). 2000. Integrated Assessment of Hypoxia in the Northern Gulf of Mexico. National Science and Technology Council, Washington, D.C.

DiAz, R. J. 2001. Overview of hypoxia around the world. Journal of Environmental Quality 30:275-281.

Diaz, R. J., J. Nestlerode, AND M. L. Diaz. 2004. A global perspective on the effects of eutrophication and hypoxia on aquatic biota, p. 1-33. In G. L. Rupp and M. D. White (eds.), Proceedings of the 7 th International Symposium on Fish Physiology, Toxicology and Water Quality, Tallinn, Estonia. EPA 600/R-04/049, U.S. Environmental Protection Agency, Ecosystems Research Division, Athens, Georgia.

Diaz, R. J. AND R. RosenberG. 1995. Marine benthic hypoxia: A review of its ecological effects and the behavioural responses of benthic macrofauna. Oceanography and Marine Biology: An Annual Review 33:245-303.

Dinnel, S. P. And W. J. Wiseman JR. 1986. Fresh-water on the Louisiana and Texas Shelf. Continental Shelf Research 6:765-784.

DONNER, S. AND D. SCAVIA. 2007. How climate controls the flux of nitrogen by the Mississippi River and the development of hypoxia in the Gulf of Mexico. Limnology and Oceanography 52 : $856-861$.

Donner, S. D., M. T. Coe, J. D. Lenters, T. E. Twine, And J. A. FOLEY. 2002. Modeling the impact of hydrological changes on nitrate transport in the Mississippi River Basin from 1955 to 1994. Global Biochemical Cycles 16:10.1029/2001GB001396.

Dortch, Q., N. N. Rabalais, R. E. Turner, and G. T. Rowe. 1994. Respiration rates and hypoxia on the Louisiana shelf. Estuaries 17:862-872.

Duan, S. And T. S. Bianchi. 2006. Seasonal changes in the abundance and composition of plant pigments in particulate organic carbon in the lower Mississippi and Pearl Rivers. Estuaries and Coasts 29:427-442.

DunN, D. D. 1996. Trends in Nutrient Inflows to the Gulf of Mexico from Streams Draining the Conterminous United States 1972-1993. U.S. Geological Survey, Water-Resources Investigations Report 96-4113. Prepared in cooperation with the U.S Environmental Protection Agency, Gulf of Mexico Program, Nutrient Enrichment Issue Committee, U.S. Geological Survey, Austin, Texas.

Dyhrman, S. T. And K. C. Ruttenberg. 2006. Presence and regulation of alkaline phosphatase activity in eukaryotic phytoplankton from the coastal ocean: Implications dissolved organic phosphorus remineralization. Limnology and Oceanography 51:1381-1390.
Galloway, J. N. AND E. B. Cowling. 2002. Reactive nitrogen and the world: Two hundred years of change. Ambio 31:64-71.

Glibert, P. M., J. Harrison, C. Heil, and S. Seitzinger. 2006. Escalating worldwide use of urea-A global change contribution to coastal eutrophication. Biogeochemistry 77:441-463.

Goolsby, D. A. 2000. Mississippi Basin nitrogen flux believed to cause Gulf hypoxia. Eos, Transactions of the American Geophysical Union 81:325-327.

Goolsby, D. A. And W. A. Battaglin. 2001. Long-term changes in concentrations and flux of nitrogen in the Mississippi River Basin, USA. Hydrologic Processes 15:1209-1226.

Goolsby, D. A., W. A. Battaglin, G. B. Lawrence, R. S. Artz, B. T. Aulenbach, R. P. Hooper, D. R. Keeney, and G. J. Stensland. 1999. Flux and Sources of Nutrients in the MississippiAtchafalaya River Basin, Topic 3 Report for the Integrated Assessment of Hypoxia in the Gulf of Mexico. National Oceanic and Atmospheric Administration Coastal Ocean Program Decision Analysis Series No. 17. National Oceanic and Atmospheric Administration Coastal Ocean Program, Silver Spring, Maryland.

Hagy, J. D., W. R. Boynton, C. W. Keefe, and K. V. Wood. 2004. Hypoxia in Chesapeake Bay, 1950-2001: Long-term change in relation to nutrient loading and river flow. Estuaries 27:634-658.

Harper, JR., D. E., L. D. McKinney, J. M. NAnce, And R. R. Salzer. 1991. Recovery responses of two benthic assemblages following an acute hypoxic event on the Texas continental shelf, northwestern Gulf of Mexico, p. 49-64. In R. V. Tyson and T. H. Pearson (eds.), Modern and Ancient Continental Shelf Anoxia, Geological Society Special Publication No. 58. The Geological Society, London, England.

Harper, JR., D. E., R. R. Salzer, and R. J. Case. 1981. The occurrence of hypoxic bottom water off the upper Texas coast and its effect on the benthic biota. Contributions in Marine Science 24:53-79.

Justić, D. 1991. A simple oxygen index for trophic state description. Marine Pollution Bulletin 22:201-204.

Justić, D., N. N. Rabalais, And R. E. Turner. 2002. Modeling the impacts of decadal changes in riverine nutrient fluxes on coastal eutrophication near the Mississippi River Delta. Ecological Modelling 152:33-46.

Justić, D., N. N. Rabalais, And R. E. Turner. 2003a. Climatic influences on riverine nitrate flux: Implications for coastal marine eutrophication and hypoxia. Estuaries 26:1-11.

Justić, D., N. N. Rabalais, And R. E. Turner. 2003b. Simulated responses of the Gulf of Mexico hypoxia to variations in climate and anthropogenic nutrient loading. Journal of Marine Systems 42:115-126.

Justić, D., N. N. Rabalais, And R. E. Turner. 2005. Coupling between climate variability and marine coastal eutrophication: Historical evidence and future outlook. Journal of Sea Research 54:25-35.

Justić, D., N. N. Rabalais, R. E. Turner, and Q. Dortch. 1995. Changes in nutrient structure of river-dominated coastal waters: Stoichiometric nutrient balance and its consequences. Estuarine, Coastal and Shelf Science 40:339-356.

KARL, T. R. AND R. W. KNIGHT. 1998. Secular trends of precipitation amount, frequency, and intensity in the United States. Bulletin of the American Meteorological Society 79:231-241.

Karlsen, A. W., T. M. Cronin, S. E. Ishman, D. A. Willard, R. Kerhin, C. W. Holmes, And M. Marot. 2000. Historical trends in Chesapeake Bay dissolved oxygen based on benthic Foraminifera from sediment cores. Estuaries 23:488-508.

KerR, R. 2006. Global warming may be homing in on Atlantic hurricanes. Science 314:910-911.

Krest, J. M., W. S. MoOre, AND Rama. 1999. ${ }^{226} \mathrm{Ra}$ and ${ }^{228} \mathrm{Ra}$ in the mixing zones of the Mississippi and Atchafalaya Rivers: Indicators of groundwater input. Marine Chemistry 64:129-152.

Lancelot, C., J.-M. Martin, N. Patin, and Y. Zaitsev. 2002. The north-western Black Sea: A pilot site to under the complex 
interaction between human activities and the coastal environment. Estuarine and Continental Shelf Science 54:279-283.

LIMNO-TECH, INC. 1995. Estimated Responses of Water Quality on the Louisiana Inner Shelf to Nutrient Load Reductions in the Mississippi and Atchafalaya Rivers. Revised Final Report to U.S. Environmental Protection Agency, Gulf of Mexico Program Office, John C. Stennis Space Center, Mississippi.

Mann, M. E. And K. A. Emanual. 2006. Atlantic hurricane trends linked to climate change. Eos, Transactions of the American Geophysical Union 87:233-244.

McCoy, C., D. R. Corbett, B. A. McKee, And Z. Top. 2007. An evaluation of submarine groundwater discharge along the continental shelf of Louisiana using a multiple tracer approach. Journal of Geophysical Research - Oceans 112, C03013, doi:10.1029/2006JC003505

MEADE, R. H. (ED.). 1995. Contaminants in the Mississippi River, 1987-1992. U.S. Geological Survey Circular 1133, U.S. Department of the Interior, U.S. Geological Survey, Denver, Colorado.

MEE, L. D. 1992. The Black Sea in crisis: A need for concerted international effort. Ambio 21:278-286.

MEE, L. D. 2001. Eutrophication in the Black Sea and a basin-wide approach to its control, p. 71-91. In B. von Bodungen and R. K. Turner (eds.), Science and Integrated Coastal Management, Dahlem University Press, Berlin, Germany.

Mee, L. D., J. J. Friedrich, AND M. T. GomoiU. 2005. Restoring the Black Sea in times of uncertainty. Oceanography 8:100-111.

Miller, J. R. AND G. L. Russell. 1992. The impact of global warming on river runoff. Journal of Geophysical. Research 97:27572764.

Milliman, J. D. AND R. H. Meade. 1983. World-wide delivery of river sediment to the oceans. Journal of Geology 91:1-21.

MississipPI River/Gulf OF Mexico WATERShed Nutrient TASK Force. 2001. Action Plan for Reducing, Mitigating, and Controlling Hypoxia in the Northern Gulf of Mexico. Office of Wetlands, Oceans, and Watersheds, U.S. Environmental Protection Agency, Washington, D.C.

Mitsch, W. J., J. W. Day Jr., J. W. Gilliam, P. M. Groffman, D. L. Hey, G. W. RANDAll, AND N. WANG. 2001. Reducing nitrogen loading to the Gulf of Mexico from the Mississippi River basin: Strategies to counter a persistent ecological problem. BioScience 51:373-388.

National Research Council. 2000. Clean Coastal Waters. Understanding and Reducing the Effects of Nutrient Pollution. National Academy Press, Washington, D.C.

Nelsen, T. A., P. Blackwelder, T. Hood, B. McKee, N. Romer, C. Alvarez-ZARIKIAN, AND S. METZ. 1994. Time-based correlation of biogenic, lithogenic and authigenic sediment components with anthropogenic inputs in the Gulf of Mexico NECOP study area. Estuaries 17:873-885.

Nürnberg, G. 2004. Quantified hypoxia and anoxia in lakes and reservoirs. TheScientifWorldJOURNAL 4:42-54. DOI 10.1100/ tsw.2004.5.

Osterman, L. E., R. Z. Poore, P. W. Swarzenski, And R. E. Turner. 2005. Reconstructing a 180-yr record of natural and anthropogenic induced low-oxygen conditions from Louisiana continental shelf sediments. Geology 33:329-333.

Parsons, M., Q. Dortch, And R. E. Turner. 2002. Sedimentological evidence of an increase in Pseudo-nitzschia (Bacillariophyceae) abundance in response to coastal eutrophication. Limnology and Oceanography 47:551-558.

Platon, E. And B. K. Sen Gupta. 2001. Foraminiferal communities of oxygen-stressed environments on the Louisiana continental shelf, p. 147-163. In N. N. Rabalais and R. E. Turner (eds.), Coastal Hypoxia: Consequences for Living Resources and Ecosystems. Coastal and Estuarine Studies 58, American Geophysical Union, Washington, D.C.

Platon, E., B. K. Sen Gupta, N. N. Rabalais, and R. E. Turner. 2005. Effect of seasonal hypoxia on the benthic foraminiferal community of the Louisiana inner continental shelf: The 20th century record. Marine Micropaleontology 54:263-283.

PokRYFKI, L. AND R. E. RANDALL. 1987. Nearshore hypoxia in the bottom water of the northwestern Gulf of Mexico from 1981 to 1984. Marine Environmental Research 22:75-90.

Rabalais, N. N. 1992. An Updated Summary of Status and Trends in Indicators of Nutrient Enrichment in the Gulf of Mexico. Report to Gulf of Mexico Program, Nutrient Enrichment Subcommittee. Publication No. EPA/800-R-92-004, U.S. Environmental Protection Agency, Office of Water, Gulf of Mexico Program, Stennis Space Center, Mississippi.

Rabalais, N. N. 2004. Eutrophication, p. 819-865. In A. R. Robinson, J. McCarthy, and B. J. Rothschild (eds.), The Global Coastal Ocean: Multiscale Interdisciplinary Processes, The Sea, Volume 13, Harvard University Press, Cambridge, Massachusetts.

Rabalais, N. N., N. Atilla, C. Normandeau, and R. E. Turner. 2004. Ecosystem history of the Mississippi River-influenced continental shelf revealed through preserved phytoplankton pigments. Marine Pollution Bulletin 49:537-547.

Rabalais, N. N., D. E. Harper JR., And R. E. Turner. 2001. Responses of nekton and demersal and benthic fauna to decreasing oxygen concentrations, p. 115-128. In $\mathrm{N}$. N. Rabalais and R. E. Turner (eds.), Coastal Hypoxia: Consequences for Living Resources and Ecosystems. Coastal and Estuarine Studies 58, American Geophysical Union, Washington, D.C.

Rabalais, N. N. AND R. E. Turner. 2001. Hypoxia in the Northern Gulf of Mexico: Description, causes and change, p. 1-36. In N. N. Rabalais and R. E. Turner (eds.), Coastal Hypoxia: Consequences for Living Resources and Ecosystems. Coastal and Estuarine Studies 58, American Geophysical Union, Washington, D.C.

Rabalais, N. N. AND R. E. Turner. 2006. Oxygen depletion in the Gulf of Mexico adjacent to the Mississippi River, p. 222-245. In L. N. Neretin (ed.), Past and Present Marine Water Column Anoxia. NATO Science Series: IV-Earth and Environmental Sciences, Kluwer Academic Publishers, Dordrecht, The Netherlands.

Rabalais, N. N., R. E. Turner, Q. Dortch, D. Justić, V. J. Bierman, JR., AND W. J. WiSEMAN JR. 2002b. Review. Nutrient-enhanced productivity in the northern Gulf of Mexico: Past, present and future. Hydrobiologia 475/476:39-63.

Rabalais, N. N., R. E. Turner, D. Justić, Q. Dortch, and W. J. Wiseman JR. 1999. Characterization of Hypoxia: Topic 1 Report for the Integrated Assessment of Hypoxia in the Gulf of Mexico. NOAA Coastal Ocean Program Decision Analysis Series No. 15. NOAA Coastal Ocean Program, Silver Spring, Maryland.

Rabalais, N. N., R. E. Turner, D. Justić, Q. Dortch, W. J. Wiseman JR., AND B. K. SEN Gupta. 1996. Nutrient changes in the Mississippi River and system responses on the adjacent continental shelf. Estuaries 19:386-407.

Rabalais, N. N., R. E. Turner, D. Justić, Q. Dortch, W. J. Wiseman JR., And B. K. Sen Gupta. 2000. Gulf of Mexico biological system responses to nutrient changes in the Mississippi River, p. 242-268. In J. E. Hobbie (ed.), Estuarine Science: A Synthetic Approach to Research and Practice. Island Press, Washington, D.C.

Rabalais, N. N., R. E. Turner, and D. Scavia. 2002a. Beyond science into policy: Gulf of Mexico hypoxia and the Mississippi River. BioScience 52:129-142.

Rabalais, N. N., R. E. Turner, B. K. Sen Gupta, E. Platon, and M. L. PARSONS. 2007. Sediments tell the history of eutrophication and hypoxia in the northern Gulf of Mexico. Ecological Applications 17 Supplement:S129-S143.

Rabalais, N. N., R. E. Turner, And W. J. Wiseman JR. 2002c. Hypoxia in the Gulf of Mexico, a.k.a. "The Dead Zone." Annual Review of Ecology and Systematics 33:235-263.

Rabalais, N. N., R. E. TuRner, W. J. Wiseman JR., AND D. F. BOEsch. 1991. A brief summary of hypoxia on the northern Gulf of 
Mexico continental shelf: 1985-1988, p. 35-47. In R. V. Tyson and T. H. Pearson (eds.), Modern and Ancient Continental Shelf Anoxia, Geological Society Special Publication No. 58, The Geological Society, London, England.

Rabalais, N. N., R. E. Turner, W. J. Wiseman JR., AND Q. Dortch. 1998. Consequences of the 1993 Mississippi River Flood in the Gulf of Mexico. Regulated Rivers: Research and Management 14: 161-177.

Rabalais, N. N., W. J. Wiseman JR., and R. E. Turner. 1994. Comparison of continuous records of near-bottom dissolved oxygen from the hypoxia zone along the Louisiana coast. Estuaries 17:850-861.

Reuss, M. 1998. Designing the Bayous: The Control of Water in the Atchafalaya Basin, 1800-1995. U.S. Army Corps of Engineers, Office of History, Alexandria, Virginia.

SCAVia, D., D. Justić, And V. J. Bierman JR. 2004. Reducing hypoxia in the Gulf of Mexico: Advice from three models. Estuaries 27:419-425.

Scavia, D., N. N. Rabalais, R. E. Turner, D. Justić, and W. J. Wiseman JR. 2003. Predicting the response of Gulf of Mexico hypoxia to variations in Mississippi River nitrogen load. Limnology and Oceanography 48:951-956.

Sen Gupta, B. K., R. E. Turner, and N. N. Rabalais. 1996. Seasonal oxygen depletion in continental shelf waters of Louisiana: Historical record of benthic foraminifers. Geology 24:227-230.

Smith, S. R. ANd G. A. Jacobs. 2005. Seasonal circulation fields in the northern Gulf of Mexico calculated by assimilating current meter, shipboard ADCP, and drifter data simultaneously with the shallow water equations. Continental Shelf Research 25:157183.

Stow, C. A., S. S. Qian, And J. K. Craig. 2005. Declining threshold for hypoxia in the Gulf of Mexico. Environmental Science and Technology 39:716-723.

Sylvan, J. B., Q. Dortch, D. M. Nelson, A. F. Maier Brown, W. Morrison, AND J. W. Ammerman. 2006. Phosphorus limits phytoplankton growth on the Louisiana shelf during the period of hypoxia formation. Environmental Science and Technology 40: $7548-7553$

Thomas, E., T. Gapotchenko, J. C. Varekamp, E. L. Mecray, and M. R. B TER BRINK. 2000. Benthic Foraminifera and environmental changes in Long Island Sound. Journal of Coastal Research 16:641-645.

Tolmazin, R. 1985. Changing coastal oceanography of the Black Sea. I. Northwestern shelf. Progress in Oceanography 15:217-276.

Trefry, J. H., S. Metz, R. P. Trogine, and B. J. Eadie. 1994. Transport of particulate organic carbon by the Mississippi River and its fate in the Gulf of Mexico. Estuaries 17:839-849.

TrenberTh, K. 2005. Uncertainty in hurricanes and global warming. Science 308:1753-1754.

Turner, R. E. AND R. L. Allen. 1982. Bottom water oxygen concentration in the Mississippi River Delta Bight. Contributions in Marine Science 25:161-172.

Turner, R. E., C. S. Milan, and N. N. Rabalais. 2004. A retrospective analysis of trace metals, $\mathrm{C}, \mathrm{N}$ and diatom remnants in sediments from the Mississippi River delta shelf. Marine Pollution Bulletin 49:548-556.

Turner, R. E., N. Qureshi, N. N. Rabalais, Q. Dortch, D. Justić, R. F. SHAW, AND J. Cope. 1998. Fluctuating silicate:nitrate ratios and coastal plankton food webs. Proceedings of the National Academy of Science, USA 95:13048-13051.
Turner, R. E. AND N. N. Rabalais. 1991. Changes in Mississippi River water quality this century. Implications for coastal food webs. BioScience 41:140-148.

TuRner, R. E. AND N. N. Rabalais. 1994. Coastal eutrophication near the Mississippi river delta. Nature 368:619-621.

Turner, R. E. AND N. N. Rabalais. 2003. Linking landscape and water quality in the Mississippi River basin for 200 years. BioScience 53:563-572.

Turner, R. E., N. N. Rabalais, R. B. Alexander, G. Mcisaac, and R. W. Howarth. 2007. Characterization of Nutrient, Organic Carbon, and Sediment Loads and Concentrations from the Mississippi River into the Northern Gulf of Mexico. Estuaries and Coasts 30:773-790.

Turner, R. E., N. N. Rabalais, And D. Justić. 2006. Predicting summer hypoxia in the northern Gulf of Mexico: Riverine N, P and Si loading. Marine Pollution Bulletin 52:139-148.

Turner, R. E., N. N. Rabalais, D. Justić, and Q. Dortch. 2003. Global patterns of dissolved $\mathrm{N}, \mathrm{P}$ and $\mathrm{Si}$ in large rivers. Biogeochemistry 64:297-317.

Turner, R. E., N. N. Rabalais, E. M. Swenson, M. KasprZak, and T. ROMAIRE. 2005. Summer hypoxia in the northern Gulf of Mexico and its prediction from 1978 to 1995. Marine Environmental Research 59:65-77.

Wiseman, JR., W. J., N. N. Rabalais, R. E. Turner, S. P. Dinnel, and A. MacNaughton. 1997. Seasonal and interannual variability within the Louisiana Coastal Current: Stratification and hypoxia. Journal of Marine Systems 12:237-248.

Wiseman, JR., W. J., N. N. Rabalais, R. E. Turner, and D. Justić. 2004. Hypoxia and the Physics of the Louisiana Coastal Current, p. 359-273. In J. C. J. Nihoul (ed.), Dying and Dead Seas, NATO Advanced Research Workshop, Liège, Belgium: NATO ASI Series, Kluwer Academic Publishers, Dordrecht, The Netherlands.

WOLOCK, D. M. AND G. J. MCCABE. 1999. Estimates of runoff using water-balance and atmospheric general circulation models. Journal of the American Water Resources Association 35:1341-1350.

WONG, G. T. F. AND P. G. BREWER. 1977. The marine chemistry of iodine in anoxic basins. Geochimica et Cosmochimica Acta 41:151159.

ZAITSEV, Y. P. 1992. Recent changes in the trophic structure of the Black Sea. Fisheries Oceanography 1:180-189.

\section{SOURCES OF UNPUblished MATERIALS}

Brunner, C. A. unpublished data. Final Report Sea Grant Project No. R/CEH-22-PD. Department of Marine Sciences, University of Southern Mississippi, 1020 Balch Blvd., Stennis Space Center, Mississippi 39529.

Dimarco, S. unpublished data. Texas A\&M University, Department of Oceanography, College Station, Texas 77843.

National Marine Fisheries Service. unpublished data. Annual Southeast Area Monitoring and Assessment Program (SEAMAP) Cruises, 3209 Fredrick Street, Pascagoula, Mississippi 39567.

Received, October 5, 2006 Revised, May 3, 2007 Accepted, June 21, 2007 